ҚАЗАҚСТАН РЕСПУБЛИКАСЫ

ҰЛТТЫҚ ҒЫЛЫМ АКАДЕМИЯСЫНЫН

АБАЙ АТЫНДАҒЫ ҚАЗАҚ ҰЛТТЫҚ

ПЕДАГОГИКАЛЫҚ УНИВЕРСИТЕТІНІҢ

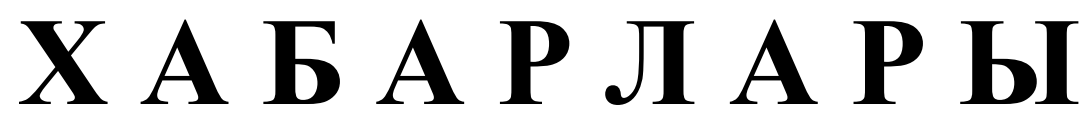

\section{ИЗВЕСТИЯ}

НАЦИОНАЛЬНОЙ АКАДЕМИИ НАУК РЕСПУБЛИКИ КАЗАХСТАН

КАЗАХСКИЙ НАЦИОНАЛЬНЫЙ

ПЕДАГОГИЧЕСКИЙ УНИВЕРСИТЕТ ИМ. АБАЯ

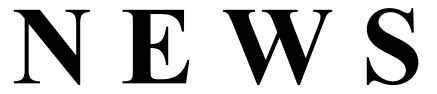

OF THE NATIONAL ACADEMY OF SCIENCES OF THE REPUBLIC OF KAZAKHSTAN

ABAY KAZAKH NATIONAL PEDAGOGICAL UNIVERSITY

ҚОҒАМДЫҚ ЖӘНЕ ГУМАНИТАРЛЫҚ ҒЫЛЫМДАР СЕРИЯСЫ

СЕРИЯ ОБЩЕСТВЕННЫХ И ГУМАНИТАРНЫХ НАУК

SERIES OF SOCIAL AND HUMAN SCIENCES

\author{
6 (322) \\ ҚАРАША - ЖЕЛТОҚСАН 2018 ж. \\ НОЯБРЬ - ДЕКАБРЬ 2018 Г. \\ NOVEMBER - DECEMBER 2018 \\ ИЗДАЕТСЯ С ЯНВАРЯ 1962 ГОДА \\ PUBLISHED SINCE JANUARY 1962 \\ ЖЫЛЫНА 6 РЕТ ШЫҒАДЫ \\ ВЫХОДИТ 6 РАЗ В ГОД \\ PUBLISHED 6 TIMES A YEAR
}

1962 ЖЫЛДЫҢ ҚАНТАР АЙЫНАН ШЫҒА БАСТАҒАН 
Ба с ре дактор

ҚР ҰҒА кұрметті мүшесі

Балықбаев Т.O.

Р е д а ц и я а лқ а сы:

экон. ғ. докторы, проф., ҚР ҰҒА академигі Баймұратов У.Б.; тарих ғ. докторы, проф., ҚР ҰҒА академигі Байпақов К.М.; филос. ғ.докторы, проф., ҚР ҰҒА академигі Есім Г.Е.; фил. ғ. докторы,, проф., ҚР ҰҒА академигі Қирабаев С.С.; эк. ғ. докторы, проф., ҚР ҰҒА академигі Кошанов А.К.; эк.ғ. докторы, проф., ҚР ҰҒА академигі Нәрібаев К.Н. (бас редактордың орынбасары); филос. ғ.докторы, проф., ҚР ҰҒА академигі Нысанбаев А.Н.; заң ғ. докторы, проф., ҚР ҰҒА академигі Сәбікенов С.Н.; заң ғ. докторы, проф., ҚР ҰҒА академигі Сүлейменов М.К.; эк. ғ. докторы, проф., ҚР ҰҒА академигі Сатыбалдин С.С.; тарих ғ. докторы, проф., ҚР ҰҒА академик Әбжанов Х.М.; тарих ғ. докторы, проф., ҚР ҰҒА корр. мүшесі Әбусеитова М.Х.; тарих ғ. докторы, проф., ҚР ҰҒА академик Байтанаев Б.А.; филол. ғ. докторы, проф., ҚР ҰҒА корр. мүшесі Жақып Б.А.; фил. ғ. докторы, проф., академик НАН РК Қалижанов У.К.; филол. ғ. докторы, проф., ҚР ҰҒА академик Қамзабекұлы Д.; тарих ғ. докторы, проф., ҚР ҰҒА академик Қожамжарова Д.П.; тарих ғ. докторы, проф., ҚР ҰҒА академик Койгелдиев М.К.; фил. ғ. докторы, проф., ҚР ҰҒА корр. мүшесі Кұрманбайұлы Ш.; тарих ғ. докторы, проф., ҚР ҰҒА корр. мүшесі Таймағанбетов Ж.К.; социол. ғ. докторы, проф., ҚР ҰҒА корр. мүшесі Шәукенова 3.К.; фил. ғ. докторы, проф., КР ҰҒА корр. мүшесі Дербісәлі А.; саяси. ғ. докторы, проф., Бижанов А.К., тарих ғ. докторы, проф., Кабульдинов 3.Е.; фил. ғ. докторы, проф., ҚР ҰҒА корр мүшесі Қажыбек Е.3.

\section{Р едакция ке н е с i:}

Молдова Республикасының ҰҒА академигі Белостечник Г. (Молдова); Әзірбайжан ҰҒА академигі Велиханлы Н. (Азербайджан); Тәжікстан ҰҒА академигі Назаров Т.Н. (Тәжікстан); Молдова Республикасының ҰҒА академигі Рошка А. (Молдова); Молдова Республикасының ҰҒА академигі Руснак Г. (Молдова); Әзірбайжан ҰҒА корр. мүшесі Мурадов Ш. (Әзірбайжан); Әзірбайжан ҰҒА корр. мүшесі Сафарова 3. (Әзірбайжан); э. ғ. д., проф. Василенко В.Н. (Украина); заң ғ. докт., проф. Устименко В.А. (Украина)

«Қазақстан Республикасы Ұлттық ғылым академиясының Хабарлары. Қоғамдық және гуманитарлық ғылымдар сериясы». ISSN 2224-5294

Меншіктенуші: «Қазақстан Республикасының Ұлттық ғылым академиясы» РҚБ (Алматы қ.)

Қазақстан республикасының Мәдениет пен ақпарат министрлігінің Ақпарат және мұрағат комитетінде 30.04.2010 ж. берілген № 10894-Ж мерзімдік басылым тіркеуіне қойылу туралы куәлік

Мерзімділігі: жылына 6 рет.

Тиражы: 500 дана.

Редакцияның мекенжайы: 050010, Алматы қ., Шевченко көш., 28, 219 бөл., 220, тел.: 272-13-19, 272-13-18, http://nauka-nanrk.kz. social-human.kz

(C) Қазақстан Республикасының Ұлттық ғылым академиясы, 2018

Типографияның мекенжайы: «Аруна» ЖК, Алматы қ., Муратбаева көш., 75. 
Главный редактор

Почетный член НАН РК

T.O. Балыкбаев

Р е дак ци онн а я коллег и я:

докт. экон. Н., проф., академик НАН РК У.Б. Баймуратов; докт. ист. н., проф., академик НАН РК К.М. Байпаков; докт. филос. Н., проф., академик НАН РК Г.Е. Есим; докт. фил. Н., проф., академик НАН РК С.С. Кирабаев; докт. экон. Н., проф., академик НАН РК А.К. Кошанов; докт. экон. Н., проф., академик НАН РК К.Н. Нарибаев (заместитель главного редактора); докт. филос. н., проф., академик НАН РК А.Н. Нысанбаев; докт. юр. Н., проф., академик НАН РК С.Н. Сабикенов; докт. юр. н., проф., академик НАН РК М.К. Сулейменов; докт. экон. Н., проф., академик НАН РК С.С. Сатубалдин; докт. ист. н., проф., академик НАН РК Х.М. Абжанов; докт. ист. н., проф., чл.-корр. НАН РК М.Х. Абусеитова; докт. ист. н., проф., академик НАН РК Б.А. Байтанаев; докт. фил. н., проф., чл.-корр. НАН РК Б.А. Жакып; докт. фиолол. н., проф., академик НАН РК У.К. Калижанов; докт. фил. н., проф., академик НАН РК Д. Камзабекулы; докт. ист. н., проф., академик НАН РК Д.П. Кожамжарова; докт. ист. н., проф., академик НАН РК М.К. Койгельдиев; докт. филол. н., проф., чл.-корр. НАН РК Ш. Курманбайулы; докт. ист. н., проф., чл.корр. НАН РК Ж.К. Таймаганбетов; докт. социол. н., проф., чл.-корр. НАН РК З.К. Шаукенова; д. филол. н., проф., чл.-корр. НАН РК А. Дербисали; доктор политических наук, проф., Бижанов А.К.; доктор ист. наук, проф., Кабульдинов 3.Е.; доктор филол. н., проф., член-корр. НАН РК Қажыбек Е.3.

Р е дак ци онны й с ов ет

академик НАН Республики Молдова Г. Белостечник (Молдова); академик НАН Азербайджанской Республики Н. Велиханлы (Азербайджан); академик НАН Республики Таджикистан Т.Н. Назаров (Таджикистан); академик НАН Республики Молдова А. Рошка (Молдова); академик НАН Республики Молдова Г. Руснак (Молдова); чл.-корр. НАН Азербайджанской Республики Ш. Мурадов (Азербайджан), член-корр. НАН Азербайджанской Республики 3.Сафарова (Азербайджан); д. э. н., проф. В.Н. Василенко (Украина); д.ю.н., проф. В.А. Устименко (Украина)

Известия Национальной академии наук Республики Казахстан. Серия общественных и гуманитарных наук. ISSN 2224-5294

Собственник: РОО «Национальная академия наук Республики Казахстан» (г. Алматы)

Свидетельство о постановке на учет периодического печатного издания в Комитете информации и архивов

Министерства культуры и информации Республики Казахстан № 10894-Ж, выданное 30.04.2010 г.

Периодичность 6 раз в год

Тираж: 500 экземпляров

Адрес редакции: 050010, г. Алматы, ул. Шевченко, 28, ком. 219, 220, тел. 272-13-19, 272-13-18, www:nauka-nanrk.kz / social-human.kz

(C) Национальная академия наук Республики Казахстан, 2018 г.

Адрес типографии: ИП «Аруна», г. Алматы, ул. Муратбаева, 75

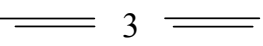


Chief Editor

\section{Honorary member of NAS RK \\ Balykbayev T.O}

Editorial board:

Doctor of economics, prof, academician of NAS RK Baimuratov U.B.; doctor of history, prof, academician of NAS RK Baipakov K.M.; doctor of philosophy, prof, academician of NAS RK Esim G.E.; doctor of philology, prof, academician of NAS RK Kirabayev S.S.; doctor of economics, prof, academician of NAS RK Koshanov A.K.; doctor of economics, prof, academician of NAS RK Naribayev K.N. (deputy editor-in-chief); doctor of philosophy, prof, academician of NAS RK Nyssanbayev A.N.; doctor of law, prof, academician of NAS RK Sabikenov S.N.; doctor of law, prof, academician of NAS RK Suleymenov M.K.; doctor of economy, prof, academician of NAS RK Satybaldin S.S.; doctor of history, prof, academician of NAS RK Abzhanov H.M; doctor of history, prof, corresponding member of NAS RK Abuseitova M.H.; doctor of history, prof, academician of NAS RK Baitanaev B.A.; doctor of philology, prof, corresponding member of NAS RK Zhakyp B.A.; doctor of philology, prof, academician of NAS RK Kalizhanov U.K.; doctor of philology, prof, academician of NAS RK Hamzabekuly D.; doctor of history, prof, academician of NAS RK Kozhamzharova D.P.; doctor of history, prof, academician of NAS RK Koigeldiev M.K.; doctor of philology, prof, corresponding member of NAS RK Kurmanbaiuly Sh.; doctor of history, prof, academician of NAS RK Taimaganbetov J.K.; doctor of sociology, prof, corresponding member of NAS RK Shaukenova Z.K.; doctor of philology, prof, corresponding member of NAS RK Derbisali A.; doctor of political science, prof Bizhanov A.K; doctor of History, prof Kabuldinov Z.E.; doctor of philology, prof, corresponding member of NAS RK Kazhybek E.Z.

\section{Editorial staff:}

Academician NAS Republic of Moldova Belostechnik.G (Moldova); Academician NAS Republic of Azerbaijan Velikhanli N. (Azerbaijan); Academician NAS Republic of Tajikistan Nazarov T.N. (Tajikistan); Academician NAS Republic of Moldova Roshka A. (Moldova) Academician NAS Republic of Moldova Rusnak G. (Moldova); Corresponding member of the NAS Republic of Azerbaijan Muradov Sh. (Azerbaijan); Corresponding member of the NAS Republic of Azerbaijan Safarova Z. (Azerbaijan); Associate professor of Economics Vasilenko V.N. (Ukraine), Associate professor of Law Ustimenko V.A. (Ukraine)

News of the National Academy of Sciences of the Republic of Kazakhstan. Series of Social and Humanities. ISSN 2224-5294

Owner: RPA "National Academy of Sciences of the Republic of Kazakhstan" (Almaty)

The certificate of registration of a periodic printed publication in the Committee of information and archives of the Ministry of culture and information of the Republic of Kazakhstan N 10894-Ж, issued 30.04.2010

Periodicity: 6 times a year

Circulation: 500 copies

Editorial address: 28, Shevchenko str., of. 219, 220, Almaty, 050010, tel. 272-13-19, 272-13-18, www:nauka-nanrk.kz / social-human.kz

(C) National Academy of Sciences of the Republic of Kazakhstan, 2018

Address of printing house: ST "Aruna", 75, Muratbayev str, Almaty 
N E W S

OF THE NATIONAL ACADEMY OF SCIENCES OF THE REPUBLIC OF KAZAKHSTAN

SERIES OF SOCIAL AND HUMAN SCIENCES

ISSN 2224-5294

https://doi.org/10.32014/2018.2224-5294.35

Volume 6, Number 322 (2018), $51-66$

\author{
D.K. Kenzhebayeva ${ }^{1}$, B.G. Urmurzina ${ }^{2}$, Dashqin Mahammadli ${ }^{3}$ \\ ${ }^{1}$ L.N.Gumilyov Eurasian National University, Astana, Kazakhstan; \\ ${ }^{2}$ K. Zhubanov Aktobe Regional State University, Aktobe, Kazakhstan; \\ ${ }^{3}$ Baku State University, Baku, Azerbayjan \\ danaa088@gmail.com,Urmurzina58@mail.ru, dashqin.muhammedli@mail.ru
}

\title{
THE MODERN YOUTH VALUES IN KAZAKHSTAN
}

\begin{abstract}
Today scientists define youth as the social and demographic group of society allocated on the basis of a set of characteristics. These features are a result of a social status, the social and psychological qualities are reflection of the development level of social and economic, cultural, features of socialization in society. Youth in the context of our research is the social and demographic group enduring the period of formation of a social maturity when they are ready to enter into the adult world, adaptations to it. Borders of this group are indistinct and mobile, but they are usually connected with age by 15-27 years. The concept of value has the complicated definition which is defined by unity of objective and subjective factors. Values in our understanding are any material or ideal phenomena for the sake of which the individual, the social group, society make efforts that to receive them, to keep and possess them, that is values are reasons of what people live and that is appreciated. Formation of values is influenced by such factors as personal age, cultural. The family economic and social situation, socio-political situations in society, an environment, a geographical location influence on youth valuable orientations. The mobility of individual and group youth consciousness is defined by an instability of a social status, public status, the uncertainty of the role structures characteristic of this social group. Problems with youth arise in connection with the aspiration of various forces to manipulate their consciousness, to exploit young people. To define the system of values of youth, it is necessary to understand in what environment they were brought up and what events were witnessed. Our research is based on the National Report "Youth" 2013, 2016 and 2017; sociological research "Youth of Central Asia" of Fund of Friedrich Ebert; data of media. In the study, we placed emphasis on the following groups' values: Family, Religion, Education, Political activity and Migration moods. It should be noted the fact that data of various sociological researches show various moods of youth.
\end{abstract}

Keywords: youth, youth policy, values, family, religion, education, migration.

The problem of values is one of most studied in science long ago. The concept of value has the problematic nature which is defined by unity of objective and subjective factors. Values in our understanding are any material or ideal phenomena for the sake of which the individual, the social group, society make efforts that to receive them, to keep and possess them, that is values are for the sake of what people live, and that is appreciated. From the sociological point of view valuable consciousness of the person, in particular, of the younger generation, is defined and develops in the course of socialization when by it it is acquired values in society. Their formation is influenced by such factors as personal, age, cultural. In other words, there is a significant dependence of formation of valuable orientations of the younger generation on the following factors: birthplace, residence (city or village), region, the financial position of family and many other things. Influence formation and development of valuable orientations of youth also: family economic and social situation, socio-political situations in society, an environment, a geographical location. The mobility of individual and group youth consciousness is defined by the instability of social status, not the formation of the public status, the uncertainty of the role structures characteristic of this social group. It in many respects explains the problems arising in the spiritual life of youth: spirituality, deformation of values, destruction of moral standards, aggression, antisocial and countercultural manifestations. Also, problems with youth arise in connection with the aspiration of various forces to manipulate her consciousness, to exploit young people. 
In our article, we use the social stratification by class property principle - a distinctive feature of modern youth, as well as society in general. During the Soviet period, it was possible to speak about youth in general. Nowadays when we speak about "youth" we have to specify urban or rural, Kazakhs or Russian, educated or even not finished. The term 'youth' describes a big social group of people.

In modern Kazakhstan, young people are in excellent starting conditions. The situation is reflected very precisely by a saying "At one Russian cabbage soup are liquid, at others pearls are small." It is typical for the developed specific capitalist society with its "animal" rules. According to the Committee on Statistics, at the beginning of 2017 the number of young people aged 14-28 was 3,994,393 people or $22.3 \%$ of the total population of Kazakhstan. At the same time, in urban areas there are 2274524 people or $56.9 \%$ of young people, in rural areas - 1719940 people or $43.1 \%$. Regionally, the largest number of young people is in South Kazakhstan region - 700,722 people or $24.3 \%$ of the total numbers of the region, the smallest number of young people live in North Kazakhstan region - 107,108 people or $19 \%$ of the total number of the region.

The age structure of Kazakhstan's youth at the beginning of 2017 is represented by three groups: the youngest (14-18 years old) - 1116126 people or 27.9\%, the average (19-23 years old) - 1284937 people or $32.3 \%$, the senior $24-28$ years old) - 1593330 people or $39.9 \%$, which is the most numerous.

In terms of gender, young people are represented almost equally: men - 2016915 people or $50.5 \%$, women - 1977478 people or $49.5 \%$. At the same time there are significant gender discrepancies in the regions: the cities of Astana, Almaty are characterized by the predominance of young women, for other regions - young men.

Based on the results of the Global Youth Development Index (2016), Kazakhstan, with a total score of 0.668 points, ranks 61 among 183 countries and belongs to a group of countries with a high level of youth development. In 2016 the leaders of this rating were Germany - the 1st place (0.894 points), Denmark - the 2 nd place ( 0.865 points), Australia - the 3 rd place ( 0.838 points), which belong to the group of countries with very high level of youth development.

\section{Youth policy: goals and tasks}

The goal of the state youth policy is to create conditions for the full spiritual, cultural, educational, professional and physical development of young people, to participate in the decision-making process, successful socialization and channeling its potential for further development of the country.

The tasks of the state youth policy are:

1. protection of rights and legitimate interests of young people;

2. involvement of youth in the socio-economic and socio-political life of the country;

3. education of citizenship and strengthening of the sense of Kazakhstan patriotism.

Currently, the formation and implementation of the youth policy, as well as inter-sectoral coordination is carried out by the Ministry for Religious and Civil Society Affairs of Kazakhstan. Over the entire period, beginning in 1998, the youth policy was gradually administered by three Ministries (the Ministry of Culture, Information and Public Consent, the Ministry of Culture, the Ministry of Education and Science).

Over the years, the state has adopted special state programs, concepts and regulatory legal acts (RLA) aimed at developing and supporting the youth (Table 1).

When preparing this article and the section of the same name in the National report, the results of mass sociological surveys of the research center "Youth" were shown, which were commissioned by the order of the Ministry of Education and Science of the Republic of Kazakhstan in 2017, are given. The volume of the Republican sample for each study comprised 2000 young respondents. The study used comparative, comparative-historical, empirical, systemic, sociological methods and content analysis.

"Today's youth of Kazakhstan is a generation that was born and grew up in a period of serious political, social and economic transformations. These are young people with their worldview, their position and their values. That is why the study of today's youth, their familiarity with the world, is important," said Tolganai Umbetaliyeva, head of the FES office in Almaty and one of the authors of the research during its presentation.

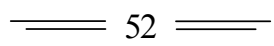


Table 1 - Youth State programs

\begin{tabular}{|c|c|c|}
\hline No & The name of the program & Responsible state agency \\
\hline 1 & The concept of the State Youth Policy 1999 & \multirow{2}{*}{$\begin{array}{l}\text { Ministry of Culture, Information and } \\
\text { Public Accord }\end{array}$} \\
\hline 2. & The program "Youth of Kazakhstan" 2001 & \\
\hline 3. & Youth Policy Program 2003-2004 & \multirow[t]{2}{*}{ Ministry of Culture } \\
\hline 4. & $\begin{array}{l}\text { Law of the Republic of Kazakhstan of July 7, } 2004 \text { No. 581-II "On State } \\
\text { Youth Policy in the Republic of Kazakhstan" }\end{array}$ & \\
\hline 5. & Youth Policy Program 2005-2007 & \multirow{7}{*}{$\begin{array}{l}\text { The Ministry of Education and Science } \\
\text { (since September 13, 2016 years- } \\
\text { Ministry of Religious Affairs } \\
\text { and Dr. grazh anskogo Society) }\end{array}$} \\
\hline 6. & $\begin{array}{l}\text { State program of patriotic education of citizens of the Republic of } \\
\text { Kazakhstan for 2006-2008 }\end{array}$ & \\
\hline 7. & $\begin{array}{l}\text { State Program for the Development of Education of the Republic of } \\
\text { Kazakhstan for 2011-2020 }\end{array}$ & \\
\hline 8. & $\begin{array}{l}\text { The concept of the state youth policy of the Republic of Kazakhstan until } \\
2020 \text { "Kazakhstan 2020: The path to the future" }\end{array}$ & \\
\hline 9. & $\begin{array}{l}\text { Plan of measures for the implementation of the Concept of the state } \\
\text { youth policy of the Republic of Kazakhstan up to } 2020 \text { "Kazakhstan } \\
\text { 2020: A path to the future" (the first stage - 2013-2015) }\end{array}$ & \\
\hline 10. & $\begin{array}{l}\text { Law of the Republic of Kazakhstan dated February 9, } 2015 \\
\text { No. 285- V "On State Youth Policy" }\end{array}$ & \\
\hline 11. & $\begin{array}{l}\text { Plan of measures for the implementation of the Concept of the state } \\
\text { youth policy of the Republic of Kazakhstan up to } 2020 \text { "Kazakhstan } \\
\text { 2020: The path to the future" ( second stage -2016-2020) }\end{array}$ & \\
\hline
\end{tabular}

"Value" is defined as the importance, significance, benefit, utility of something. Externally, the value acts as a property of the object or phenomenon. However, significance and usefulness are inherent not in nature, not merely because of the internal structure of the object itself, but as subjective assessments of specific properties that are involved in the sphere of human social life, a person is interested in them or needs. The system of values plays the role of everyday orientations in the subject and social reality of a person, the designations of his various practical attitudes towards the surrounding objects and phenomena.

The norms that have taken shape in society are the highest expression of the value system (that is, the prevailing ideas about what is considered good, right, or desirable). The concept of values and norms differ. Values - these are abstract, general concepts, and norms - these are rules or guidelines for behavior in certain situations. The system of values prevailing in society plays a vital role since it affects the content of norms. All norms reflect social values. The system of values can show the norms prevailing in society.

Moral values are the most critical element of the internal structure of personality, which provides and shows the degree of its maturity and sociality, determines the very essence of a social individual, the state of development of the inner world of a person, his mind, character, consciousness, conscience, soul, characterizes his level of humanity.

At the same time, in order to improve the implementation of the state youth policy, the Youth Policy Council of the President of Kazakhstan was established by the Decree of the Head of State on July 1, 2008. Its main tasks include the development of recommendations for the implementation of a comprehensive state policy on youth, informing the President of Kazakhstan on the situation in the youth environment, and analyzing the effectiveness of implementing the state youth policy. Following the results of the recent meeting held on April 13, 2018 in Shymkent, the Secretary of State Gulshara Abdykalikova gave instructions on the formation of values for young people and the organization of leisure.

Dosym Satpayev provides the following facts regarding the education level of Kazakhstan unemployed population: 117,900 people $(24.9 \%)$ have a higher education, 174,800 people $(36.9 \%)$ have a general secondary education, 124,800 people $(26.4 \%)$ have a specialized secondary education (Satpayev, 2013). Consequently, we can see from the statistics that in many circumstances unemployment is rather high among the youth who did not acquire the higher or specialized education. These factors do not give an opportunity to describe the full picture of the youth unemployment in Kazakhstan labor market. The existence of the mentioned problems confirmed the sociological research results of "Zhastar" Research Center. For example, according to conducted social researches, among the problems raising difficulties in getting an employment for the young people there are: no employment history (22\%), low salary (17\%), 
employers' corruption, bribe-taking (13\%), discrepancy between acquired education and market requirements (11\%), young specialists' low competitive ability in the labor market (10\%), no work places in the districts they live (10\%). Respondents to the survey also mark they wish there was discrimination concerning gender and nationality (correspondingly, 3\% and 4\%) (Kazakhstan youth, 2013).

"The Kazakhstan truth" in 2013 published an article about youth values on the base of study of Institute of philosophy, political science and religious studies of RK. The representative sociological poll $(\mathrm{N}=1000)$ was the youth in an age interval from 18 to 29 years. The survey was conducted in all regions of Kazakhstan taking into account their ethnic, sexual, educational structure.

One of the key differentiating indicators of value orientations of young people is the personal assessment by them the importance of various spheres of activity. In this regard, it was offered to respondents to give such an assessment.

It agrees to the data obtained as a result of the poll, for the Kazakhstan youth the most important reference points traditionally are "The family, education, work".

According to Talgat Kaliyev the number one value of youth is "Family" (84\%), "Health" - 61,1 percent. The young people include "Love" in a scale of values - 19,8\%, "Knowledge and education" $17 \%$, "Work and an interesting profession" - 10\%. "Material success" - 23\%. The scale of values at our youth quite traditional also answers signs of safe society.

According to some scholars the crisis of a family, a decreasing role of "husband" and cause an impact on the personality. The report of 2013 in Kazakhstan shows apparently that family sees one of the significant vital values. Traditionally Kazakhs pay great attention to the family unit and relative connection. The market economy puts a person in a different situation when the man has to take care more about his interests.

Thus a particular influence of an ethnic origin on distinctions in the definition of is revealed that it is the most important for representatives of the younger generation in life. Owing to essential numerical prevalence in the country in general and in regions of the population of the Kazakh and Russian nationality the comparative analysis of answers of respondents of these two primary and most significant data files is carried out.

The results of the sociological survey conducted by the "Youth" research center in 2017 showed that the most important values for Kazakhstan's youth are family $-82.4 \%$, health $-57.5 \%$, friendship - $32 \%$ of respondents (Table 2). In comparison with the results of the previous year, certain changes in the values of the youth have taken place. Thus, young respondents estimated the value of friendship higher than the material security in life - $32 \%$ compared to $15.8 \%$, respectively; and they leaned toward love over career values.

Table 2 - The degree of importance of the basic life values of the youth

\begin{tabular}{|l|l|c|}
\hline \multicolumn{1}{|c|}{ Survey year } & Top -5 values & \% \\
\hline \multirow{4}{*}{2017 year } & $1 . \quad$ Family & $82.4 \%$ \\
\cline { 2 - 3 } & $2 . \quad$ Health & $57.5 \%$ \\
\cline { 2 - 3 } & $3 . \quad$ Friendship & $32.0 \%$ \\
\cline { 2 - 3 } & $4 . \quad$ Financially Secure Life & $15.8 \%$ \\
\cline { 2 - 3 } & $5 . \quad$ Love & $5.5 \%$ \\
\hline \multirow{4}{*}{2016 year } & $1 . \quad$ Happiness in Family & $74.1 \%$ \\
\cline { 2 - 3 } & $2 . \quad$ Health & $56.7 \%$ \\
\cline { 2 - 3 } & $3 . \quad$ Wealth & $36.0 \%$ \\
\cline { 2 - 3 } & $4 . \quad$ Honest Friends & $29.8 \%$ \\
\cline { 2 - 3 } & $5 . \quad$ Job & $18.6 \%$ \\
\hline
\end{tabular}

Source: National reports "Youth of Kazakhstan-2016", "Youth of Kazakhstan -2017" (* in the process of the survey, respondents chose no more than three answers)

At the same time, the values of freedom, independence, and happiness mean little to the Kazakh youth, gaining a maximum of 0.2 . Thus, the value of freedom and independence understood both as personal and as a whole, of one's country, the state, does not have a pronounced priority. As can be seen, these spiritual values are not significant enough, which is an indirect manifestation of certain conformity of the youth. 
For the young people of all the age groups of Kazakhstan, to be happy is an abstract and insignificant category, occupying the last place in the line of preferences, not even reaching $0.5 \%$. Also, the young people do not consider seeing the world and travelling as the main goal, apparently believing that becoming financially secure (1st position), having a good family (2nd position), being a professional (3rd), becoming a worthy citizen (4th), being famous, while maintaining the quality of an honest and principled person, a sense of happiness and the opportunity to travel will come together with all this.

The older the young people are, the less altruistic they are: helping people is not such an important value for the respondents. The young people of Kazakhstan are focused on work as the basis of all their future achievements, believing that to achieve these goals it is necessary to work tirelessly. This is the opinion of the vast majority of the respondents, agreeing that "work is a vital need of a person, contributing to the development of their personality". It is logical, however, that the largest number of those who doubt that "work does not always contribute to success, the main thing in life is luck, good family and friendship ties" belongs among the non-studying, non-working and non-job-seeking youth $(22.3 \%)$.

The results of sociological research have shown the absolute dominant orientation of the young people to the patriarchal type of interactions between spouses.

The youth of Kazakhstan in most cases does not choose the egalitarian (partner) model of family relations, based on the recognition of equal rights and responsibilities of spouses, and is inclined towards the patriarchal type of interactions between spouses in the family, as demonstrated, e.g., by the European youth, where the results of similar studies indicate a high starting readiness of spouses for competition (struggle) for leadership and advocacy of individual interests. All the three age cohorts are in solidarity in the distribution of future/present role - playing roles in the family: the male - breadwinner, the female keeper of the family hearth.

It should be noted that the older the youth, the more family and health values, as the most important two pillars, play a role in life. Among all the age groups, social acceptance plays a less important role.

In the ranking of values, the Kazakh youth considers family as an absolute value among all the three age groups. Moreover, there is a tendency: the older and more mature young people are, the greater is the importance attached to the institution of the family in their value hierarchy: $85.8 \%$ of the young aged $24-$ 29 years, $78.8 \%$ of those aged $19-23$ years, $80.5 \%$ of those aged 14 to 18 years. The family, according to almost $79 \%$ of the respondents, is responsible for the spiritual and moral education of Kazakh youth (to be kind, honest, responsible, etc.). At the same time, the role of the school, state bodies for the support and development of young people, religious institutions, and unions of peers is noted.

For the Kazakh youth, the most important spheres of life are: "A family, children, the house" $-72,5 \%$, "Study, education" - 62,9\%, "Work, business" - 51,6\% of respondents. For the Russian youth, the same values are in the top three, but there are distinctions in gradation and indicators of their values. For them "A family, children, the house" - 76,4\%, on the second - "Work, business" - 50,5\% also are in the first place. Moreover, "Study, education" close the three of values with considerably smaller value $-45,8 \%$ (see the chart).

As for a vital assessment "Pits, promotions," and insignificant, but the quite noticeable difference is observed here. So, if among Kazakh respondents it is essential for 17,7\%, among the Russian youth - for $22,2 \%$ of respondents.

The indicator following on a general meaning for all respondents costs, apparently from data of the table, importance of "Leisure, entertainments, tourism." Thus 12,1\% of Kazakhs and 20,8\% of the Russian respondents attach to this sphere of life importance.

Very indicative information on tendencies of an ideological and valuable condition of the youth environment is given by the data of poll showing the attitude to religious belief. Essential for themselves to it was called by $8,1 \%$ of Kazakhs and only $3,3 \%$ of the Russian young people. We could draw a preliminary conclusion on that, now the Kazakh youth, unlike the recent past, in a much more significant degree the Russian youth are Orthodoxal. This subject demands separate particular profound opinion poll owing to the ideological relevance. 


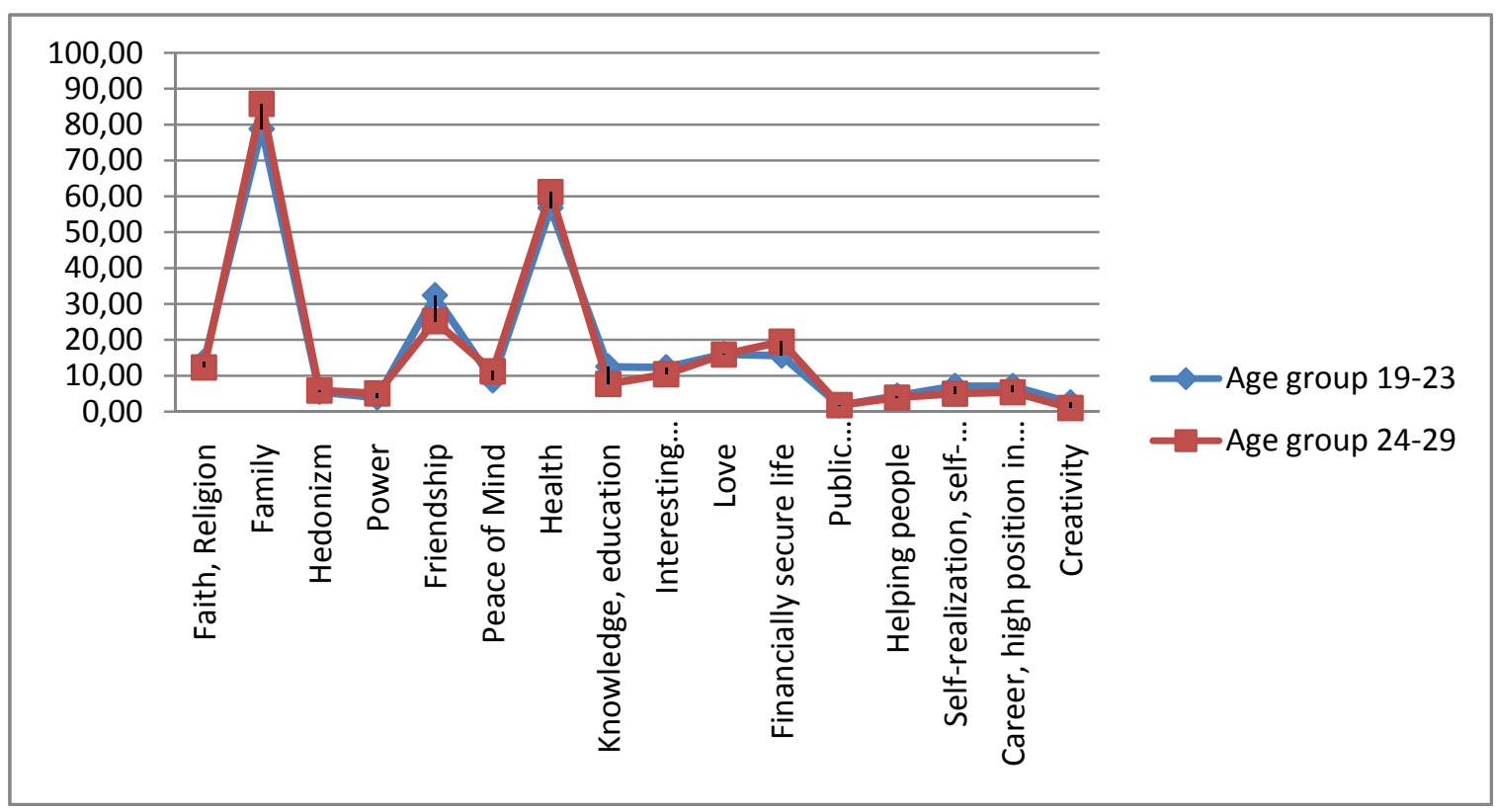

Figure 1 - Youth Values (2018)

Exciting data are obtained in the analysis of the results of the poll on a cut "city village." So, for rural respondents in general two most important spheres are "A family, children, the house" $-82,6 \%$, and also "Work, business" - 57,4\%. While among city respondents these spheres were called by important considerably smaller part of respondents $-69,7 \%$ and $46,4 \%$ of respondents respectively. It testifies that, despite processes of urbanization and change of social mentality, in the environment of rural youth value of valuable traditional orientation "The house, a family, work" is still much more significant (see table 2).

On the other hand, in the city it is more, than in the village, youth career, promotion" (the city $22,9 \%$, the village $-11,1 \%)$, "Leisure, entertainments, tourism" $(15,2 \%-10,8 \%)$, "Physical culture, sport" attaches significance to such spheres, as "(12,8\% - 5,2\% respectively). These essential distinctions are connected not only with valuable personal orientations but also that the rural youth in a much more significant degree, than citizens, is limited in equal real opportunities.

Further on all massif of the values interrogated in general in gradation follow: "Career, promotion," "Leisure, entertainments, tourism," "Physical culture, sport." Moreover, in the last place there were in this pyramid "A religion, public and political work." This subject also has to become a subject of individual research. Nevertheless the obtained data already rather eloquently testify that the Kazakhstan youth does not attach great value to the ideological sphere, public work and policy, that is is very slightly ideologized and politized.

Thus, for the modern younger generation the most significant are such values, as "A family, children, the house," "Study and education," "Work and business" today. These positions, on the one hand, remain traditionally crucial for the Kazakhstan youth. However, with another - today they can be considered and as result of the accruing individualization of social consciousness in the conditions of post-socialist capitalization of society.

The publication was prepared on the basis of sociological research that was conducted in 2014, which covered 1,000 of the country's young men aged 14 to 29 from all 14 regions of Kazakhstan, as well as the cities of Almaty and Astana. The methodology of the well-known Shell Youth Study was used for the research. It was adapted for the conditions and features of Kazakhstan. The survey was focused on the main spheres of attention of Kazakh youth, their dreams and plans, values, views, as well questions and issues which they face within the socialisation process. Here are the highlights of the survey that can be downloaded online on the FES website.

Religion and religious values

According to the research, the religious view of Kazakh youth is complicated. They assess religion positively but claim they don't comply with many parts of religions. A quarter of the respondents say they 
have not decided their religion; 29.1 percent say they doubt if there is heaven and hell and 21 percent are not sure about the statement that "the God has created the world." Mainly most of the respondents call themselves believers, while 19.4 percent say they are non-religious or atheists.

Regional differences

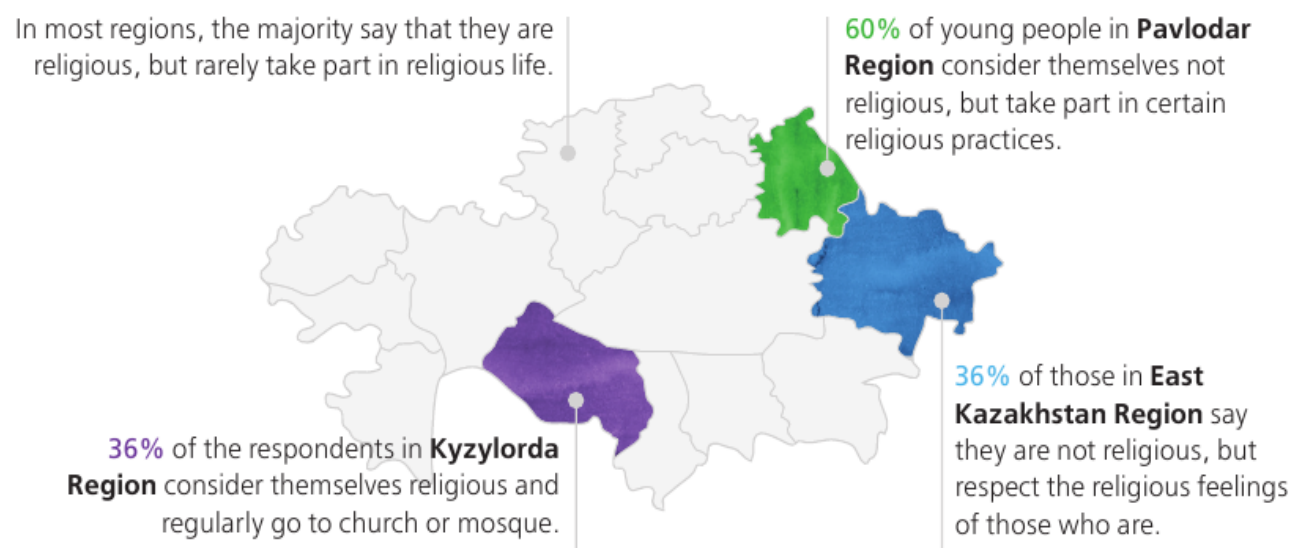

Figure 2 - Religion

According to Summers (2017) in the last decades, the religious situation in the Kazakhstan has changed: the rapidly growth of believers, construction of religious building, increased number of discussions about religious education and growth number of fasting people. Data of sociological researches show that if in 2003 number of people who have called themselves "religious people" were $38,7 \%$, results of study in 2013 showed a rapidly increased "religious people" - 73,9\%. As we see in last 10 years the percent of religiousness in youth has practically doubled.

Institute of Philosophy, Political Science, and Religious Studies MES RK provided monitoring studies. The sample consisted of 3000 adult respondents from 14 regions of Kazakhstan, and Astana and Almaty (in 2012-2013) with coverage of 1000 respondents (in 2014). Participants were students, undergraduates of pedagogical and technical specialties, and civil servants, former adherents of religious movements, pensioners, etc.

One of the first questions in the study was: "How did you choose your worldview?". The majority of respondents $37.8 \%$ answer that the choice of the world outlook has been formed since childhood, this fact confirms the existing theories of duality of religion in Kazakhstan and the strong influence of folk traditions inculcated since childhood. More than $25 \%$ have formed a current worldview over the past 10 years. Unfortunately, the researchers do not comment on this fact, and we do not know which religion the respondents chose. However, the fact that most of the respondents were students; and the fact of the growth of religious self-awareness in the last 25 years, may become possible answers to this question.

The study shows that the religious choice of participants is largely predetermined by the closest environment: relatives, friends, neighbors (46.9\%). The second most important motivational factor is the mood in the society (15.4\%). The third place in the motivational structure of each tenth respondent associated with the impact of special literature and Internet resources $(10.3 \%)$. Missionaries $(8.0 \%)$ are in the fourth place in terms of influence on the religious choice of the individual, and on the fifth - the influence of fashion trends on religiousness in society (5.1\%).

Researchers have noted the fact that in comparison with earlier studies $(2000,2005)$ sociological monitoring of 2014 shows the essential growth of respondents who project the future of Kazakhstan as a religious country (dynamics, according to the measurements taken in similar methodological tradition and a methodical paradigm increases from $4,1 \%$ at the beginning of 2000 up to $7,8 \%$ in 2005 to $13,6 \%$ respectively in 2014).

The data analysis of participant's expectation towards future of their children investigated with a question «How do you think what kind of relationship with Religion would have your children?" showed a strong family influence on a choice of religion. For third part of respondents $(32.6 \%)$ the future of their 
children have a strong tights with religion, and $66,7 \%$ would like to see them respecting religion. $12,1 \%$ would prefer that children would be indifferent to religion, and 9,3\% hope that they would be atheist.

Another interesting result was shown in a recent study (Telebayev, 2013). Participants answered on a question "Did you hear about volunteers from Kazakhstan who are involved in Syria conflict?". More than $40 \%$ of youth gave a positive respond:

-the third part of participants claimed that "volunteers" were "representatives of the radical, fundamentalist direction", "representatives of criminal groups, bandits and criminals" (32,6\%);

-the large group of youth tried to understand them and showed "sympathizing ", believing that it were "ordinary people who have no work, of money, prospects", " the people who have got under influence of criminal groups and people" (39,3\%);

It should be noted that some participants shared their opinion that terrorist activity in Syria conducted by "true Muslims" in defense of Islam (5\%).

Another serious question is existence of real threat of religious terrorism in Republic of Kazakhstan, many experts declare a stable situation in a country. More likely, it is connected with the fact that most of them don't see distinction between traditional Islam and its radical form.

Considering amendments in law about activity of religious organization especially in their registration, all of them till October 25, 2012 passed the state re-registration.

Table 3 - Number of religious organizations

\begin{tabular}{|c|c|c|}
\hline Number of Religious Organization in Kazakhstan & Before Registration & After registration \\
\hline Islam & 2811 & 2229 \\
\hline Russian Orthodox Church & 304 & 280 \\
\hline Old ROC & 400 & 189 \\
\hline Protestants & 364 & 100 \\
\hline Catholics & 118 & 79 \\
\hline
\end{tabular}

The Constitution of the Republic of Kazakhstan fixed the secular nature of the state, determining and guaranteeing the rights of citizens to freedom of speech, thought and expression, which is also no provision for patronage or special relationship with any particular religion, declared by an equal and tolerant attitude to all religions. Accordingly, the basic principles of the Republic of Kazakhstan state policy of regulation in the field of interfaith relations as a whole are quite liberal. They clearly stated the position on religious freedom, equality, tolerance, and pluralism. The legislative and regulatory framework of interfaith relations regulated by the Law "On Freedom of Conscience and Religious Associations" of 1992, which, according to experts, to fully comply with international standards. For a complete legislative support in this sphere, settling phenomena, not provided for by law in 1992, a law was passed "On amendments and additions to some legislative acts of Kazakhstan on issues of religious freedom." There were some imbalances in education - cancel the course of religion, abolished the Religious Affairs Committee.

At the same time, open borders and liberal religious legislation of Kazakhstan contribute to strengthen and expand the field of activity of various religious groups and cults, which contributes to the massive movement into the country of foreign religious missionaries and emissaries of numerous religious and pseudo-religious communities and organizations. Some of them work illegally, as part of a secret community, but many of them quite legally engaged in the propagation of their faith by promoting an early treatment of the population of the republic in non-traditional religion for him, distant and alien to the traditional culture, the mentality of Kazakhstan.

To achieve its goals the foreign missionaries have financial incentives convert, find them jobs, contribute to the employment of their relatives and friends that find a wide response among people with low educational and cultural level and low financial status. The mechanism of expansion of the social base of foreign missionaries debugged quite effectively, as evidenced by an increased contingent convert the population. In this case, the emphasis is on the training of local personnel. For example, most of the alien religious communities, such as "Grace", "Agape", "New Life", "Bahá'í", "Jehovah's Witnesses" and a number of others are headed not foreign pastors who arrived in Kazakhstan or guidance from abroad, and ethnic Kazakhs. 
Thus, on the face of the fact of religious proselytism, i.e. the process of the active population in the treatment of other religious, implemented in Kazakhstan due to the huge financial injections from abroad. In this particular danger is the fact that the number of foreign missionaries professed non-traditional antisystemic teachings banned in many Western countries.

5th June 2016, Aktobe, terrorists attacked a military base and a weapon, civilian victims. Victims of the attack began to 19 people, among them - four civilians and three soldiers. The Ministry of Internal Affairs of Kazakhstan acknowledged took place in Aktobe attack an act of terrorism. Throughout Kazakhstan introduced moderate "yellow" mode of the terrorist threat, which will be valid for 40 days. According to information provided by the press service of Ministry of Internal Affairs of RK, killed 13 of the organized terrorist attack in Aktobe terrorists, four wounded. In addition, detained eight people suspected of involvement in extremist.

From March 2017 Parliament, President Nazarbayev N.A., ministry of religion, initiated law which would ban strictly religious attributes (e.g. paranja, nikaab) for citizens. The Ministry of Education and Science, Justice, Religious Affairs and civil society of Kazakhstan said that the wearing of religious clothing and headscarves are not allowed and were not allowed before. Ministry of Education and Science, Justice, Religious Affairs and civil society in Kazakhstan declared a ban on hijab in schools. In this regard, the Ministry of Education and Science of Kazakhstan by order of 14 January 2016 number 26 introduced common rules for school uniforms, according to which every public education institutions need to adhere to certain rules. According to the rules, uniforms include a jacket, jacket, pants, shirt front, casual shirt, skirt, blouse classical (winter variant forms: knitted vest sundress, turtleneck). Spiritual Administration of Muslims of Kazakhstan declared about the wearing of the hijab in schools in Kazakhstan. The SAMK noted that first of all children should receive education. According SAMK parents should not encumber their underage daughters for wearing a headscarf.

The study provided on 5534 participants showed that $51 \%$ of them supported hijab ban, $8 \%$ answered that religious dresses couldn't/t be part of official places as schools, and universities; $37 \%$ didn't support changes.

\section{Family and marriage}

The research showed that 75.9 percent of youth think marriage and creation of the family is paramount, while 1.5 percent imagines their lives without a partner and obligations. Among life priorities, being married is more important than getting a high education or making a career. The average age for the creation of family is 22 years for women and 25 for men. On average, Kazakh youth want to have three children.

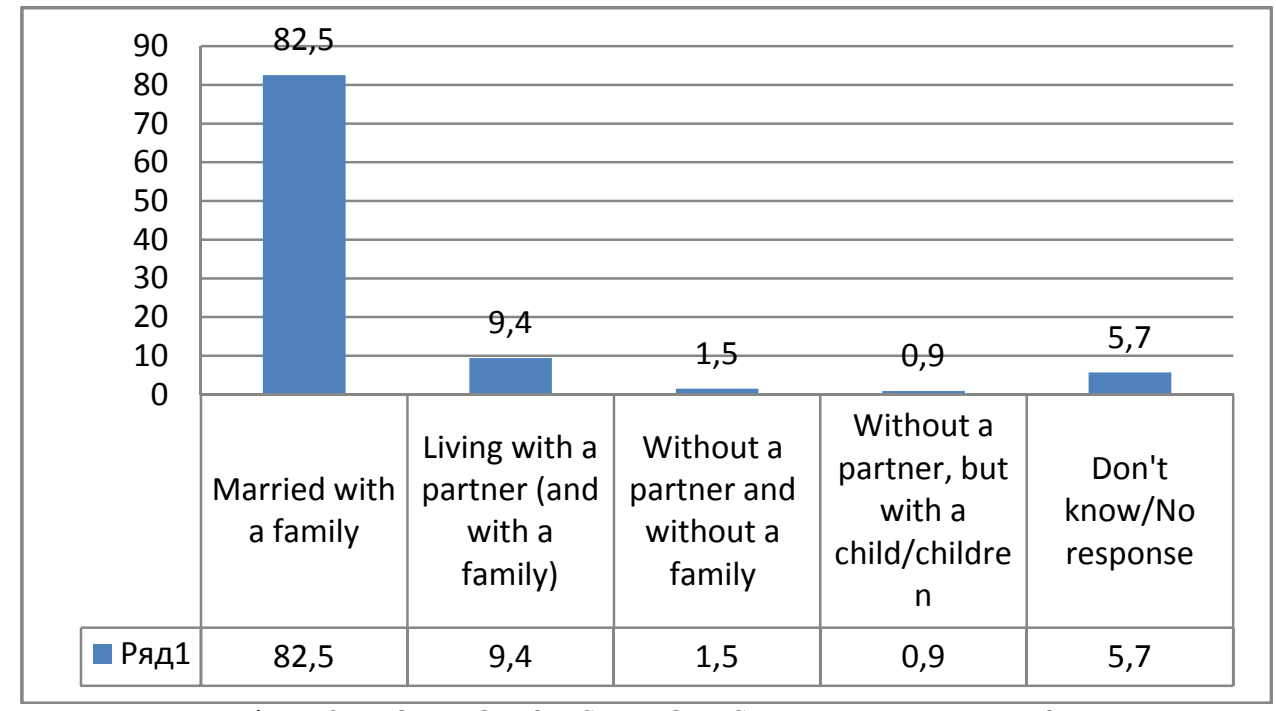

Figure 3 - HOW DO YOU SEE YOURSELF IN THE FUTURE?

\section{The role of older generation and family}

A major part of the respondents positively assess their relations with parents (94.6 percent) and siblings (90 percent). About 37 percent said their fathers play an important role in making decisions, while 
31.3 percent said their mothers. But at the same time, 86.7 percent think they are not under heavy pressure while making decisions. Approximately 54.4 percent said they make decisions jointly with their parents. Only 10.6 percent said their parents make decisions for them.

Figure 23

HOW IMPORTANT DO YOU THINK BELONGING TO A JÜZ (HORDE) OR CLAN IS IN KAZAKHSTAN? (of the 637 Kazakh respondents who were asked this question)

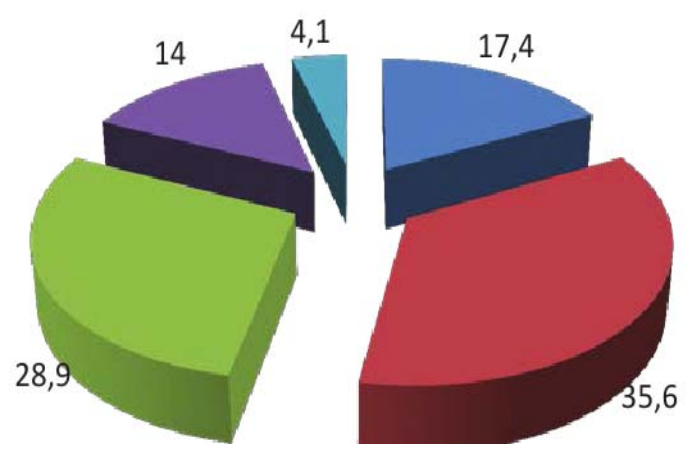

- Very important

- Fairly important

Fairly unimportant

- Very unimportant

Don't know

Figure 4 - Tribal System in Kazakhstan

\section{Education}

Education itself is losing its attractiveness to youth, the survey says. 72.3 percent said they need a diploma mostly for the fact that it increases the chances of getting a job, while 30.5 percent said they need higher education to meet the expectations of their parents. Almost 48 percent would prefer to study abroad and 17.7 percent would like to study in Kazakhstan. The most popular destinations are Russia, the United States, countries of the European Union and South Korea.

\section{THE IMPORTANCE OF HIGHER EDUCATION AND MARRIAGE (by sex)}

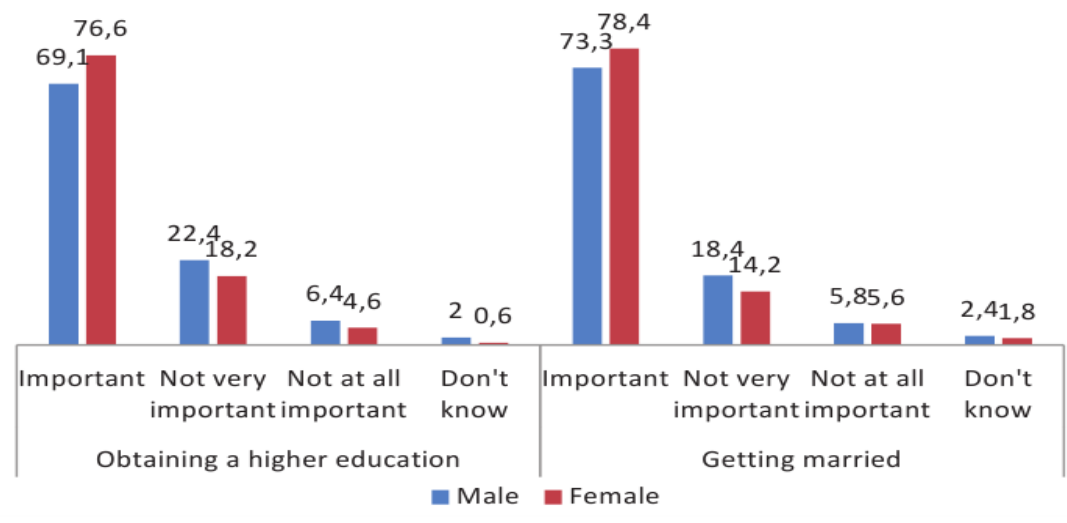

Figure 5 - The role of Education

The Soviets build a strong system of education. In that time of history majority of females got opportunity to get secondary education. The level of education among women in Central Asia is still generally high. However, all countries of the region face severe problems with respect to women's labor market participation. Women still earn, on average, up to 50 per cent less than men. Rural women are particularly vulnerable due to failing infrastructure, lack of basic services and unequal access to land, property and assets. 
The reform of the general education system in the Republic of Kazakhstan describes the importance of the spiritual and moral development of the future generation. The idea of stage-by-stage modernization of national network of multilevel education by priorities of the Strategic development plan for the Republic of Kazakhstan, for improvement of the quality of preparation of human resources, the satisfaction of needs of the personality and society including spiritual. The transformations in an education system of the Republic of Kazakhstan directed to full integration into world educational space, the problem of spiritual and moral development can't be ignored the states in any way.

The development of vision, character, and competence in our young people is necessary to allow our nation to continue its role of world leader into the 21 st century rather than be relegated to history as former world leaders such as Egypt, Iran, Spain, Portugal, and Great Britain. Each of these former world powers failed to keep pace with the changing demands of the world around them. In many cases it was not a failure of the economic or material aspect of society, but rather the human, social, political, or spiritual aspects. The educational system must prepare individuals to progress in each of these arenas of life. Therefore, character development must be seen as an organic process in the development of the material/physical, human/psychological, and spiritual/transcendental aspects of human being.

\title{
WHICH OF THESE WOULD YOU CHOOSE IF YOU HAD THE CHOICE?
}
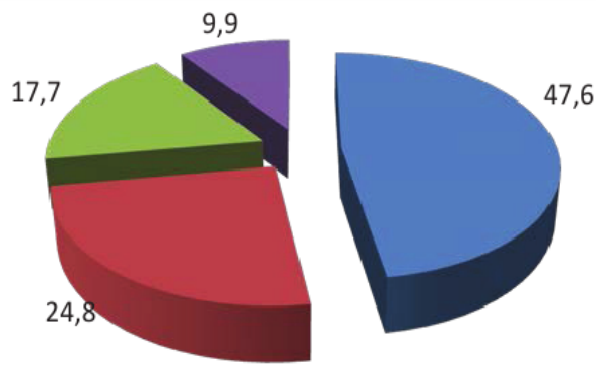

\author{
Education abroad \\ - Local education \\ - Partial education abroad \\ Don't know/No response
}

Figure 6 - Preferences in Education

The most popular country to study abroad is Russia, USA, and China. Researchers found significant differences between Russian and Kazakh participants.

\section{The role of women in Kazakh society}

The research shows that 84.8 of the youth think women in Kazakhstan have enough rights. When it comes to family, 36.5 percent think men and women are equal in a relationship. Just more than 32 percent said men are the heads of families, 9.1 percent believe women more and more are leading families. About 19 percent think women are independent. According to the authors, the large part of the youth does not support the idea of polygyny. When it comes to bride kidnapping, the opinions were divided half and half. Most of the people who were pro said that it is just a tradition and usually happens with the agreement of both sides and can save money for the bride's side.

According to Karimova (2016) the image of the mother appears to us as a woman that generates trust, happy and not prone to jealousy. Jealousy is one of the most influential human emotions, comparable with love, and with hatred. And like all other emotions is inherent only to man. Suspicion is an unpleasant, painful feeling associated with the fear of losing an object of love. Jealousy - in many ways a simple sense and always associated with the rivalry. As a rule, people who are not self-sufficient, not self-confident, or conversely too self-assured and consider a person their "property" tend to be very jealous

\section{Ensuring the rights of the citizens}

The research showed that 77.7 percent of respondents are satisfied with the level of democracy in the country. Economical position, level of education, origin (city or village) and age were called among the reasons for discrimination more than gender, religion and language. 
According to Biyekenova (2016), 58.2\% (the majority) of the respondents believe that all young people aim to become patriots, $27.3 \%$ answered that this is not necessary, and $13.9 \%$ (one-seventh) of the students selected the answer 'do not know.'

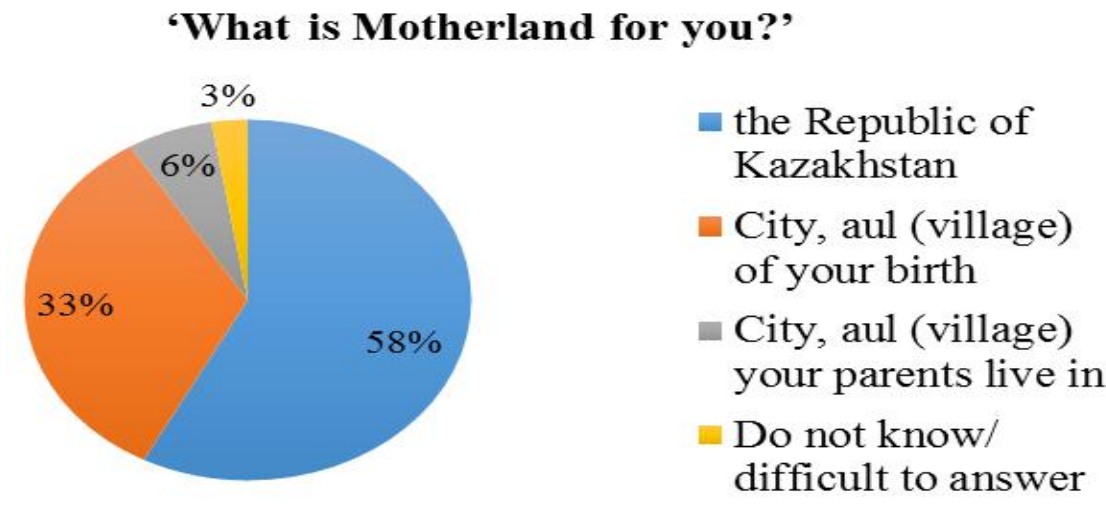

Figure 7 - Motherhood

The main question was 'Do you consider yourself a patriot?' Surprisingly, 37.6\% of the students answered 'yes,' $36.1 \%$ 'more likely yes,' $17 \%$ 'more likely no,' $5.2 \%$ 'no,' and $4.1 \%$ of the respondents found it difficult to answer the question

\section{Migration}

A major part of the participated youth connect their future with Kazakhstan (87.5 percent). About 10.5 percent intend to migrate to Russia, countries of the European Union, the U.S., Canada and China, but one third of them plan to come back in 10 years.

The stream decreasing from Kazakhstan grows four years in a row. The country last year was left by nearly two and a half times more people, than arrived. One experts explain negative balance of population shift with the social and economic reasons. Others speak about expenses of national policy.

37704 persons, according to committee on statistics of Kazakhstan, left the country last year. In comparison with 2016 the number of the left increased by 7,8 percent. In spite of the fact that the stream of the arrived increased (in 2017 arrived 16081 persons that is 20,5 percent higher, than in previous year), the balance of migration developed negative - minus 21623 persons.

The main migratory exchange of the country happened to the states of the CIS. The share arrived made 72,1 percent of these countries; a share left to the CIS countries - 89,4 percent. In a quantitative sense essential value for the analysis of external migration in 2017 has the movement of ethnic Russians which balance of migration respectively makes minus 23909 people.

In February 2018 the analytical Finprom.kz portal published research of migratory processes which authors come to conclusions that Kazakhstan leaves more and more experts. Qualified personnel in 2017 arrived to 15 percent less, than in 2015, it is noted in calculations. Their share from total of the arrived made 36 percent, in 2015 - 40,9 percent.

Outflow goes on technical specialties (6,6 thousand people), economic (3,6 thousand) and pedagogical (2,3 thousand). In 2017 to Kazakhstan there arrived 1,3 thousand technical specialists, 841 economists and 718 teachers. In these three spheres indicators of balance of migration are most negative, that is outflow of experts in these branches is not filled in a due measure; "outflow of technicians, economists and teachers is most critical" research is summarized.

Key factors of migration:

1. Lack of workplaces which will grow even more due to digitalization and a population increase.

2. Falling of the real income of the population, despite growth of economy that for citizens is even more offensive.

3. Falling of quality of the higher education at the growing prices for it.

4. Top-level corruption and irrational use of budgetary funds. Total amount of financial violations, including inefficiently used means, recorded by Calculating committee of Kazakhstan at implementation of state programs from 2013 for 2016, made 6,7 trillion tenge (or 2,07 billion dollars) at a present course. 
5. Increase of a retirement age for women till 63 years which will take place step by step, but began in 2018. The trust to pension system falls.

6. Deterioration of secondary education due to too fast introduction a multy-linguality: very few people believe that the Kazakhstan teachers for some months will master English at the level, necessary for teaching.

7. Reform of medicine: introduction of fund of medical insurance to which clinics are simply not ready physically - at them is not present medical information systems.

8. The scandals and provocations arranged by national populist and stopped by neither security officers, nor the power.

9. Constant floods which in the last some years destroy villages in the north, the center and the East of Kazakhstan, and the power cannot do anything with it.

Of course, there are problems and in other countries. But in Kazakhstan they are aggravated with the falling trust level to the power. Deficiency of coal in the coal-mining country, corruption, frankly unfair adjudications and full dispassionateness of the power from the population problems - process went especially vividly in the last 1,5 years.

One of indicators - growth of participation of the population in protest actions in the inactive earlier capital in this aspect.

All events have to set the power thinking: it hangs in emptiness, and after all a tree with the weakened roots, despite a powerful trunk and krone more and more, falls from any external push.

\section{Geopolitical priorities}

The Eurasian Economic Union was positively assessed by 90.9 percent of respondents. Young Kazakh men and women call Russia, the European Union, the Kyrgyz Republic, China and Uzbekistan among priority directions. In their opinion, more reserved relations should be with the U.S., NATO, Iran and Afghanistan. Main sources of information about politics and world events are TV (60.5 percent), internet (89.2 percent), family discussions (33.1 percent), talks with friends and relatives (16 percent) and social networks (10 percent).

Modern youth is the new people with the western type of thinking; they exist in our realities. The people who decide on a base of combined individualism and collectivism. These are people whose values are somewhat similar to instincts, then to the ideas. Moreover, at last, it is people of which unites nothing. In this light become the primary and defining influence of the state on the formation of valuable orientations of modern youth. First of all, the state has to guarantee zero tolerance to drugs policy, nonproliferation of alcohol and smoking. The state has to undertake functions not of the simple construction of sports centers (though it is essential too), but also to promote familiarizing of the youth with new actions which no political ideology. The legislative base has to provide interest of public organizations and citizens to promote moral development of the younger generation. The most talented young people in the unique scientific and educational centers have to work on the implementation of moral values among youth. Also, one of the significant factors, doing young people of persons, the education system is. Specialization and creative approach, the avoiding senseless cramming is necessary as soon as possible. At schools and the universities, the system of self-government has to work. There has to be knowledge cult. In the education of moral values media, especially if to consider that the youth does not exist without television and the Internet have to play an important role. They are capable of acquainting youth with the achievement of the world and national culture. Youth is necessary to inform of the idea on a possibility of improvement of life according to all characteristics only with their active participation.

\section{REFERENCES}

[1] Abdiraimova, G., \& Altynbekov, A. (2013). A Universal Labor Society: World experience and Kazakhstan. Materials of II International scientific and practical conference "Kazakhstan-2050” Strategy: Long-term sustainable development and priorities for further partnership with Russia" (pp. 191-198). Moscow.

[2] Address of the President of the Republic of Kazakhstan - Leader of the Nation N.A. Nazarbaev to the people of Kazakhstan. Strategy 'Kazakhstan-2050': New Political Course of the Established State, 14 December 2014, pp. 52-53.

[3] Agency of Statistics of the Republic of Kazakhstan. Department of Statistics of Almaty. (2014). The quantity of Almaty population according to gender and age. Demography, 14. Retrieved March 5, 2014, from http://almaty.gorstat.kz.

[4] Agency of the Republic of Kazakhstan for Religious Affairs. Religious associations in the Republic of Kazakhstan, Astana, 2012. 
[5] Altynbekov, A. (2014). Kazakhstan and Europe: Youth's work attitude, predominance and viewpoints. Materials International Research and Practical Conference "Psychology in Kazakhstan: Past, Nowadays and Future" Dedicated to $25^{\text {th }}$ Anniversary of Foundation of "Psychology" Department and to $80^{\text {th }}$ Anniversary of Al-Farabi Kazakh National University.Almaty.

[6] Bokanova, Z. et al.(2013). "Kazakhstan youth-2013" National report. Astana: "Zhastar" RC.

[7] Beck T. To create conditions for creativity.//Kazakhstan truth, on February-7.//www.kazpravda.kz

[8] Constitution of the Republic of Kazakhstan. Art. 20. Available at http://www.akorda.kz/ru/official_documents/constitution

[9] Demographical annual of Kazakhstan (2016) Statistics digest. RK Statistics Agency. Astana.

[10] Guide of a theologian (2014). The agency of the Republic of Kazakhstan for religion. Astana. $192 \mathrm{p}$.

[11] Institute of Education Sciences-The Education Resources Information Center (ERIC). (2014). Retrieved March 5, 2014, from http://eric.ed.gov/

[12] Kaliev, T., Kaidarova, A., Ashimkhanova, D., Sydyknazarov, M. and other (2017). National Report "Youth of Kazakhstan - 2017”. Astana: SIC Youth.

[13] Kaldybaeva, O., Kaliev, T., Nikolayeva O. (2017). Methodical recommendations "Influence of religion on the formation of the system of values of the Kazakh youth". Astana: SIC "Youth".

[14] Karimova A., Alekeshova L., Yesengulova M., Kulbaeva B.,Sarkulov M.(2015) The Social Role Approach of Family Education in Adolescents Development. European Proceedings of Social \& Behavioural Sciences. doi:10.15405/epsbs.2015.08.2

[15] Karashulakov, J.Zh. \& Ibraev, E.E. Ed. Collection of materials on the main issues of the religious sphere: To help civil servants. Astana, Agency of the RK for Religious Affairs, pp. 15-22.

[16] Kazakhstan Government (2016). The Concept of the State Youth Policy of the Republic of Kazakhstan until 2020 "Kazakhstan 2020: a way to the future (the second stage 2016-2020)", // http://adilet.zan.kz/kaz/docs/P1300000191.

[17] Kazakhstan Government (2016). Action plan for the implementation of the Concept of the state youth policy of the Republic of Kazakhstan until 2020 "Kazakhstan 2020: a way to the future (second stage 2016 - 2020)".

[18] Kosichenko, A.G. (2013). Religious consciousness of Kazakhstan and problems of improving religious policy in the republic of Kazakhstan. Proceedings of the scientific and practical conference "The held Kazakhstan, looking to the future, December 10， 2013. Http://kisi.kz/en/categories/politicheskaya-modernizaciya/posts/religioznoe-soznanie-kazahstancev-iproblemy-sovershens

[19] Kurganskay, A.G., Dunaev, V.U. and Podoprigora, V.P. (2006). The Impact of Religious Organizations on Kazakhstan'sYouth. Research Report. Rep.of Kazakhstan. Almaty

[20] Kurganskaya, V.D., Dunaev, V.Yu., Kosichenko, A.G., Podoprigora, R.A., Sadovskaya, E.Yu., Chuprynina, I.Yu. (2013). Research report "The influence of religious organizations on young people in Kazakhstan." - Almaty: Center for Humanitarian Research, 158 p.

[21]Kushzhanov N., Almurzayeva B., Shunkeeva O., Seitenova S., SummersD. ,Summers B. THE DIGITAL TRANSFORMATION OF AN EDUCATION SYSTEM. THE VIRTUAL REALITY AS NEW EDUCATIONAL SPACE. BULLETIN OF NATIONAL ACADEMY OF SCIENCES OF THE REPUBLIC OF KAZAKHSTAN ISSN 1991-3494 Volume 3, Number 373 (2018), 152 - 158. https://doi.org/10.32014/2018.2518-1467.

[22] Law Of state youth policy of the Republic of Kazakhstan No. 285. V. (2015). Retrieved March 5, 2018, from http://online.zakon.kz/Document/?doc id=31661446\#sub id=310000.

[23] Law "On Religious Activities and Religious Associations RKll. № 483-IV from 11 Oct. 2011. Available online: http://adilet.zan.kz/rus/docs/Z1100000483.

[24] Message of the President of the Republic of Kazakhstan Leader of the nation Nursultan Nazarbayev to the people of Kazakhstan "Strategy Kazakhstan-2050: a new political policy of the taken place state".//www.akorda.kz.

[25] Mager Yu. Assembly of kindness, peace and harmony.//Kazakhstan truth, on March 1, 2018 from http.//pravo.zakon.kz.

[26] Ministry of education and science of the Republic of Kazakhstan. (2012, 2015). Retrieved March 5, 2018, from http://edu.gov.kz/en.

[27] Ministry of National Economy of the Republic of Kazakhstan, Committee on Statistics. (2013, 2015). Retrieved March 5, 2018, from www.stat.gov.kz.

[28] Nazarbayev, N. (2012). Kazakhstan's Social Modernization: Twenty Steps towards a Universal Labor Society. Retrieved March 5, 2018, from http://www.egemen.kz/2012/07/10/340989.

[29] Naurzalina D. et al . (2015) The impact of family style education on high school student's grades. The European Proceedings of Social \& Behavioural Sciences eISSN: 2357-1330. doi:10.15405/epsbs.2015.08.21.

[30] Research center of "HeadHunter" company. (2015). Retrieved March 5, 2018, from http://www.hh.kz.

[31] Research center of "HeadHunter" company. (2012). Higher education and occupational work. Retrieved March 5, 2018, from http://hh.kz/file/9715722.pdf.

[32] Satpayev, D. (2013). Labor market: Flying over from the shadow to the light. Retrieved March 5, 2018, from http://forbes.kz/process/expertise/ryinok truda iz teni v svet pereletaya.

[33] Satpayev, D. (2014). We should change not ministers, but the system of their activity assessment. Retrieved May 5, 2018, from http://forbes.kz/process/expertise/menyat_nado_ne_ministrov_a_sistemu_otsenki_ih_deyatelnosti.

[34] Strategy for Gender Equality in the Republic of Kazakhstan for 2006-2016. Approved by the Decree of the President of the Republic of Kazakhstan \# 1677 of 29 November 2005. Astana, 2005. 37 p. 
[35]D. Summers , S. Salish , A. Karabalina , V. Kubieva , A. Erbulatova , B. Almurzayeva , G. Nazarova. PSYCHOLOGICAL AND PEDAGOGICAL ASPECTS OF MORAL EDUCATION IN KAZAKHSTAN. BULLETIN OF NATIONAL ACADEMY OF SCIENCES OF THE REPUBLIC OF KAZAKHSTAN ISSN 1991-3494 Volume 3, Number 373 (2018), 121 - 129. https://doi.org/10.32014/2018.2518-1467

[36] Teslenko, A.N. (2013) Cultural stratification of socialization of Kazakhstan's youth. Collected papers of the scientificpractical republican conference. g. Astana, Kazakhstan,. P. 375.

[37] The Labor Code of the Republic of Kazakhstan No. 251. (2007). Retrieved March 5, 2018, from https://www.enbek.kz/ru/normativno-pravovye-akty-v-sfere-zanjatosti/trudovoj-kodeks-respubliki-kazahstan

[38] Toguzbayev, K. (2017). As at "Witnesses" have found three painful points. Available: https://rus.azattyq.org/a/svideteli-iegovy-almaty-priostanovlenie/28604575.html. Last accessed 5th Aug 2017.

[39] UNDP (2016). Overview. Human Development. Report (2016). Human Development for Everyone. By the United Nations Development Programme. From: http://hdr.undp.org/sites/default/files/HDR2016_EN_Overview_Web.pdf.

[40] Vermenichev A. "The Mangilik Yel" - the idea which has to be present at all spheres of life of the country.//Letters, 2014. February $12 . / /$ liter.kz

[41] Yeshpanova, D., Narbekova, G., Biyekenova, N., \& Zhunusova, B. (2014). Social activity of Kazakhstan's youth in today social and political reality. Almaty: Institute for Philosophy, Political Science and Religion.

[42] Violence Against Women: Does the Government Care in Kazakhstan?, Violence Against Women (VAW) Monitoring Program, 2007.

[43]Urmurzina B.G., Utemissova G.,Uteuova A., Issatayeva B., Gavrina A.V. CROSS-CULTURAL ASPECTS OF COMPANY'S GOAL-SETTING SYSTEM AS A FORM OF MOTIVATION. BULLETIN OF NATIONAL ACADEMY OF SCIENCES OF THE REPUBLIC OF KAZAKHSTAN ISSN 1991-3494 Volume 3, Number 373 (2018), 144 - 151. https://doi.org/10.32014/2018.2518-1467

[44]Utemissova G., Summers D., Urmurzina B., Abdirakhmanova Y., Scott Alan Burton Summers. PSYCHOLINGUISTIC STUDY OF SUGGESTIVE METHODS IN EDUCATION. BULLETIN OF NATIONAL ACADEMY OF SCIENCES OF THE

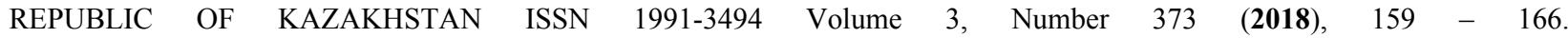
https://doi.org/10.32014/2018.2518-1467

[45] Yergaliev, E. (2017). Hijabs in Kazakhstan: "Beards and black attires - only an iceberg top". Available: https://365info.kz/2017/04/hidzhaby-v-kazahstane-borody-i-chernye-odeyaniya-eto-lish-verhushka-ajsberga/. Last accessed 5th Aug 2017.

[46] “Zhastar” Research Center. (2015). Retrieved March 5, 2018, from http://youthpolicycenter.kz/ru/institucionalnayapodsistema/nic-molodezh.html

[47] http://www.akorda.kz/ru/official documents/strategies and programs

[48] https://365info.kz/2018/07/iz-kazahstana-bessledno-ischezli-polmilliona-grazhdan-shibutov/

[49] https://kapital.kz/gosudarstvo/67369/5-interesnyh-faktov-o-kazahstanskoj-molodezhi.html

[50] https://www.zakon.kz/4856334-kazahstanskaya-molodezh-pragmatichnaya.html

[51] https://www.kazpravda.kz/news/obshchestvo/tsennostnie-orientatsii-kazahstanskoi-molodezhi/

[52] https://www.kazpravda.kz/news/obshchestvo/o-sisteme-tsennostei-kazahstanskoi-molodezhi-rasskazal-ekspert

[53] http://www.akorda.kz/ru/addresses/addresses_of_president/poslanie-prezidenta-respubliki-kazahstan-nnazarbaevanarodu-kazahstana-5-oktyabrya-2018-g

УДК 338(471)

Кенжебаева Д.к. ${ }^{1}$, Урмурзина Б.Г. ${ }^{2}$, Дашгин Махаммадли ${ }^{3}$

${ }^{1}$ ЕНУ имени Л.Н.Гумилева, Астана, Казахстан;

${ }^{2}$ Актюбинский региональный государственный университет им. К. Жубанова, Актобе, Казахстан;

${ }^{3}$ Бакинский государственный университет, Баку, Азербайджан

\section{ЦЕННОСТИ СОВРЕМЕННОЙ МОЛОДЕЖИ КАЗАХСТАНА}

Аннотация. Сегодня ученые определяют молодежь как социально-демографическую группу общества, выделяемую на основе совокупности характеристик, особенностей социального положения и обусловленных теми или другими социально-психологическими свойствами, которые определяются уровнем социальноэкономического, культурного развития, особенностями социализации в обществе. Молодежь в контексте нашего исследования - социально-демографическая группа, переживающая период становления социальной зрелости, вхождения в мир взрослых, адаптации к нему. Границы этой группы размыты и подвижны, но их обычно связывают с возрастом 15-27 лет. Понятие ценности имеет сложную природу, определяющуюся единством объективных и субъективных факторов. Ценностями в нашем понимании являются любые материальные или идеальные явления, ради которых индивид, социальная группа, общество предпринимают усилия, чтобы их получить, сохранить и обладать ими, то есть ценности - это то, ради чего люди живут и что ценят. С социологической точки зрения ценностное сознание человека, в частности, молодого поколения, определяется и развивается в процессе социализации, когда им усваивается ценности в обществе. На их формирование влияют такие факторы, как: личностный, возрастной, культурный. На формирование и 
развитие ценностных ориентаций молодежи влияют также: социально-экономическое положение семьи, социально-политические ситуации в обществе, окружение, географическое положение. Подвижность индивидуального и группового молодежного сознания определяется неустойчивостью социального положения, несформированностью общественного статуса, неопределенностью ролевых структур, характерных для этой социальной группы. Проблемы с молодежью возникает в связи со стремлением различных сил манипулировать ее сознанием, использовать молодых людей в своих интересах. Для того, чтобы определить систему ценностей молодежи, необходимо уяснить, в какой среде они воспитывались и свидетелями каких событий были. Наше исследование базируется на Национальном Докладе «Молодежь» 2013, 2016 и 2017 года; социологическое исследование «Молодежь Центральной Азии» Фонда имени Фридриха Эберта; данные СМИ. В своей работе мы сделали акцент на следующих группах ценностях: Семья, Религия, Образование, Политическая активность и Миграционные настроения. Стоит отметить тот факт, что данные различных социологических исследований показывают различные настроения молодежи.

Ключевые слова: молодежь, молодежная политика, ценности, семья, религия, образование, миграция.

\author{
Д.К. Кенжебаева ${ }^{1}$, Б. Ғ. Өрмөрза ${ }^{2}$, Дашгин Махаммадли ${ }^{3}$ \\ ${ }^{1}$ Н.Гумилев атындағы Еуразия ұлттық университеті; \\ ${ }^{2}$ Қ.Жұбанов атындағы Ақтөбе өңірлік мемлекеттік университеті; \\ 3 Бакинский государственный университет, Баку, Азербайджан
}

\title{
КАЗАҚСТАНДЫК ЗАМАНАУИ ЖАСТАРДЫН КҰНДЫЛЫҒЫ
}

\begin{abstract}
Аннотация. Бүгінгі таңда ғалымдар жастарды әлеуметтік-экономикалық деңгейі, мәдени дамуы, қоғамдағы әлеуметтену ерекшеліктерімен айқындалатын, әлеуметтік жағдай ерекшеліктері, сипаттамалар жиынтығы негізінде анықталатын қоғамдағы әлеуметтік-демографиялық топ деп белгілейді. Біздің зерттеулер тұрғысынан қарағанда жастар әлеуметтік жетілу кезеңінен өтіп, ересектер әлеміне енген, оған бейімделген әлеуметтік-демографиялық тобы болып табылады. Осы топтың шекарасы бұлыңғыр және қозғалмалы, бірақ оларды әдетте 15-27 жас аралығымен байланыстырады. Құндылық түсінігі объективті және субъективті факторлардың бірлігі арқылы анықталатын күрделі сипатқа ие. Біздің түсінігіміздегі құндылықтар кез келген материалды немесе идеалды құбылыстар болып табылады, жеке тұлға, әлеуметтік топ, қоғам оларды меңгеру, сақтау және иемдену үшін күш-жігер жұмсайды, яғни, құндылықтар - адамдардың өмір сүріп, бағалайтын нәрсесі. Әлеуметтік тұрғыдан адамның құндылық санасы, әсіресе, жас ұрпақ қоғамда құндылықтарды игерген кезде әлеуметтену процесінде анықталады және дамиды. Олардың қалыптасуына жекелік, жас ерекшелігі, мәдениеттілігі сияқты факторлар ықпал етеді. Жастардың құндылық бағдарларының қалыптасуы мен дамуына отбасының әлеуметтік-экономикалық жағдайы, қоғамдағы әлеуметтік-саяси жағдай, қоршаған орта және географиялық орналасу әсер етеді. Жеке және топтық жағдайда жастардың сана-сезімінің қозғалысы осы әлеуметтік топқа тән әлеуметтік жағдайдың тұрақсыздығы, әлеуметтік мәртебесінің қалыптаспауы, рөлдік құрылымдардың белгісіздігі арқылы анықталады. Әртүрлі күштердің жасардың сана-сезімін басқаруға, оларды өздерінің пайдасына қолдануға талпынысынан жастардың проблемалары туындайды. Жастардың құндылық жүйесін анықтау үшін, олар тәрбиеленетін ортаны және қандай оқиғалардың куәсі болғанын анықтау керек. Біздің зерттеулер 2013, 2016 және 2017 ж. «Жастар» Ұлттық дәрісіне; Фридрих Эберт атындағы қордың «Орталық Азия жастары» әлеуметтік зерттеулеріне; баспасөз деректеріне негізделген. Біз өз жұмысымызда құндылықтардың келесі топтарына назар аудардық: Отбасы, Дін, Білім, Саяси белсенділік және Көші-қон жағдайы. Түрлі әлеуметтік зерттеулердегі деректер жастардың әр түрлі көңіл-күйлерін көрсететінін атап айту керек.
\end{abstract}

Түйін сөздер: жастар, жастар саясаты, құндылықтар, отбасы, дін, білім беру, көші-қон.

Information about authors:

Kenzhebayeva Dana Kenzhegaliyevna - L.N.Gumilyov Eurasian National University, Department of Regional studies;

Urmurzina Bayan Gazizovna - Aktobe Regional State University named after K.Zhubanov, Associated Professor of the Department of Pedagogy and Psychology of the Faculty of Pedagogy, Candidate of Psychological Sciences, urmurzina58@mail.ru;

Dashqin Mahammadli - Baku State University, Faculty of Library and information, Teacher of library resourses and information retrieval systems, PhD Student, Email: dashqin.muhammedli@ mail.ru 


\section{МАЗМҰНЫ}

Беспаева Р.С., Бугубаева Р.О., Мануэль Ф. Грела2. Көрсеткіштердің теңдестірілген жүйесі негізінде Щучинск-Бурабай курорттық аймағын дамытудың кешенді стратегиясын қалыптастыру ................................................................................ 5

Аюпова 3.К., Құсайынов Д.Ө.Азаматтық процесстерді жетілдірудегі интеграцияның кейбір қырлары...................... 13

Құсайынова А. А., Вальдемар Козловски, Геращенко И. П.Қазақстан республикасындағы міндетті әлеуметтік сақтандырудың қаржылық-құқықтық тетіктерінің ерекшеліктері.

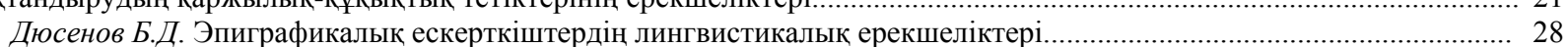

Джумадилова Ш.Г., Атабай Б.Ж. Қазақстандағы халықтың жинақтарының динамикасы......................................... 33

Карабалина А.А., Альситова А. Б., Кереймаганбетова Ж.Н., Абишева Н. М. Құндылық - рухани-адамгершілік

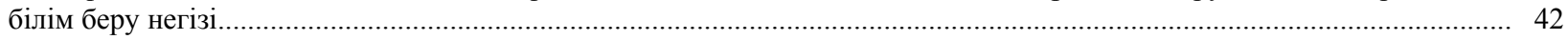

Кенжебаева Д.К., Өрмөрза Б. Ғ., Дашгин Махаммадли. Қазақстандық заманауи жастардың құндылығы............. 51

Нурманова А.Ш., Медерова Д.Е., Дюсенов Б.Д. «Бөкейхан әулетінің талдыбейіт қорымы» эпиграфикалық ескерткіштері тарихи дереккөз ретінде.

Кыдырова Ж.Ш., Онласынов Е.З., Абишова А.У., Шадиева А.А. Оңтүстік Қазақстан облысы сүт және сүт өнімдері нарығындағы жағдайды зерттеу ......

Абимова Г.У., Аманжолов Р., Мынбаева Б.Н., Ибрагимова Д.И. ЖОО-да биолог-студенттердің жобаларды

ұйымдастырылуы мен орындалуына даярлығы.......

Балтабаева А.Ю., Ризаходжаева Г. Мәдени интеграция үдерісіндегі жібек жолының феномені............................... 9

Бурганова Р.И., Абдугалина С.Е., Туякова А.Е. Студенттерге бағытталған білім беру арқылы білім сапасын

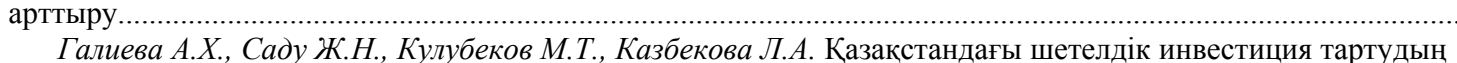

институционалдық жағдайын (талаптарын) бағалау..

Джалилов 3.Г., Батырхан Б.Ш. ХX ғ. екінші жартысындағы шетелдік исламтанушылардың ислам және саясат

туралы теориялық дискурсы.......

Джумабекова А.Т., Канатова А.Ж. Қаржылық ынтымақтастық жағдайларындағы Қазақстан республикасының

ұлттық банкінің өткізу механизмінің өзгеруі......

Дүйсен Г. М., Айтжанова Д. А. Қазақстан және Орталық Азия елдеріндегі көші-қон процесстері дамуының мәселелері мен ерекшеліктері

Есендұлова М.Н. Қазақстандағы « Қиын балаларды» оңалтудың және әлеуметтендірудің психологиялық ерекшеліктері

Жакишева К.М., Жуманова Д.Т., Мукашева Г.М. Экономиканың аграрлық секторының тұрақты дамуына арналған ауыл шаруашылық кәсіпорындарының қаржылық шарттарын мониторингінің рөлі.....

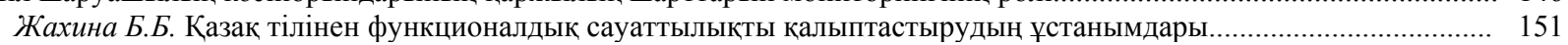

Идресова У.Х., Садуахасова 3.Ж., Муханова А.Т. Криминалистика....................................................................... 156

Савельева В. В. Қазақстандағы кредит технологиясын пайдалану және дамуының тарихи және педагогикалық базасы.

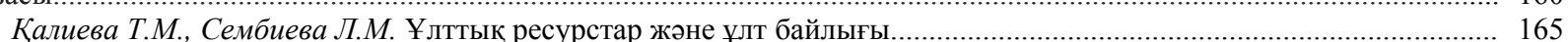

Каримова Р.У., Хаджиева Г.У. ҚХР Ұлттық саясаты контексіндегі ШҰАА-ның этносаяси және әлеуметтікэкономикалық трансформациясы мәселесі.

Керімбек Г., Молдашбаева Л., Джрауова Қ., Ажмухамедова А., Мизанова А. Қазақстан республикасының

республикалық бюджетіне түсетін салық түсімдерінің көрсеткіштерін талдау және бағалау.....

Жолдасбекова С.А., Парманкулова П.Ж., Асаналиев М.К. Мүмкіндігі шектеулі балаларды дамытудағы ұлттық ойындар

Молдакенова Е.К., Байгабулова К.К., Онаева Б.Т. БҚО-да инновациялық үрдістерді басқарудың аймақтық

аспектілігі жүйесінің дамудың жолдары.

Мұратова Г.К., Шаушенова А.Г., Жумасеитова С.Д., Онұварбаева М.Б.Білім беру үрдісінде бұлттық

технологияларын қолдану......

Несіпбеков E. Н., Аппакова Г.Н. Кәсіпорынның инвестициялық портфелін қалыптастырудың теориялық

Нургабылов М.Н., Барлыков Е.К., Егембердиева С.М. ҚР есеп өнеркәсібінің дамуының басқаруының трендсі....... 220

Нурымбетов Т.Я., Абишова А.У., Уразбаева Г.Ж., Кыдырова Ж.Ш., Байнеева П.Т., Абишо Н.У. Модернизациялық

жағдайындағы қр халқын әлеуметтік қолдауының басымдықтары.....

Рахимова С. А., Тургумбекова М. М. Қазақстан республикасындағы шағын және орта бизнестіңмемлекеттік қолдау

бағдарламалары және олардың тиімділігін жүзеге асыру шаралары.......................................................................... 233

Руденко Е.И. Орталық пен Оңтүстік Азия мемлекеттері арасындағы ұғынудың бұрмалануы - «Жұмсақ күш»

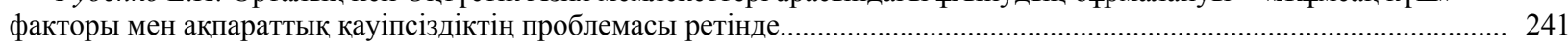

Тохтабаева Ш. Қазына-сандық.......................................................................................................... 251

Утепкалиева К.М., Сабирова Р.К., Кенбаева Г.У. Мұнай-газ секторындағы мемлекеттік-жеке серіктестікті дамыту

Мыңбаев Д. Е. Банкте басқару есебін ұйымдастыру тұжырымдамасы...

Султанова Г.С. Жаңа формацияның экономисі - бакалаврдың кәсіби құзыреттілігін қалыптастырудың

Шаяхметова А.А. Университет жағдайында инклюзивті білім беру үшін педагогтарды оқыту....... 


\section{СОДЕРЖАНИЕ}

Беспаева Р.С., Бугубаев Р.О., Мануэль Ф. Грела. Формирование комплексной стратегии развития ЩучинскоБоровской курортной зоны на основе сбалансированной системы показателей. Аюпова 3.К., Кусаинов Д.У., Уинстон Наган. Некоторые грани интеграции в совершенствовании гражданского процесса.

Кусаинова А.А., Козловски Вальдемар, Геращенко И.П. Обзор некоторых особенностей финансово-правового механизма обязательного социального страхования в республике Казахстан......

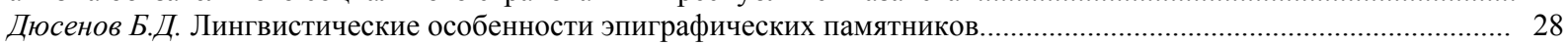

Джумадилова Ш.Г., Атабай Б.Ж.Динамика сбережений населения в Казахстане................................................... 33

Карабалина А.А., Альситова А. Б., Кереймаганбетова Ж.Н., Абишева Н. М. Ценность как базовая основа духовнонравственного образования.

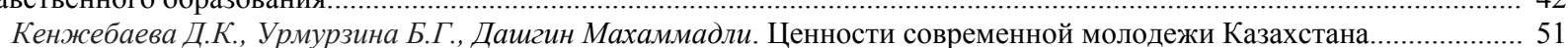

Нурманова А.Ш., Медерова Д.Е., Дюсенов Б.Д. Эпиграфические памятники «Некрополи талдыбейит династии

Бокейхановых» как исторический источник.

Кыдырова Ж.Ш., Онласынов Е.З., Абишова А.У., Шадиева А.А.Исследование ситуации на рынке молока и молочной продукции южно-казахстанской области

Абишова Г.У., Аманжолов Р., Мынбаева Б.Н., Ибрагимова Д.И. Готовность студентов-биологов к организации

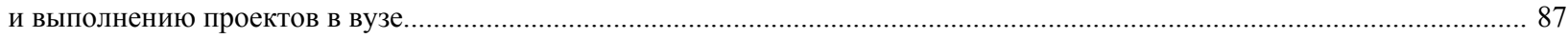

Балтабаева А.Ю., Ризаходжаева Г. Феномен великого шелкового пути в процессе культурной интеграции............... 91

Бурганова Р.И., Абдугалина С.Е., Туякова А.Е. Повышение качества образования посредством

студентоцентрированного обучения...

Галиева А.Х., Саду Ж.Н., Кулубеков М.Т., Казбекова Л.А. Оценка институциональных условий привлечения

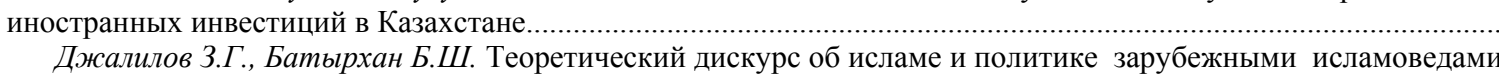
второй половины ХX в.

Джумабекова А.Т., Канатова А.Ж. Трансформация трансмиссионного механизма национального банка республики

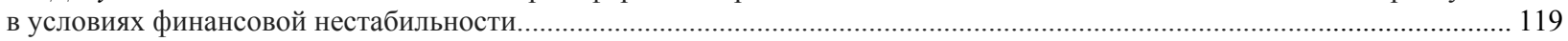

Дуйсен Г.М., Айтжанова Д.А. Проблемы и особенности развития миграционных процессов в Казахстане

и странах Центральной Азии.

Есенгулова М.Н. Психологические особенности реабилитации и социализации "Трудных подростков"

в Казахстане".

Жакишева К.М., Жуманова Д.Т., Мукашева Г.М.Роль мониторинга финансового состояния сельскохозяйственных

предприятий в обеспечении устойчивого развития аграрного сектора экономики.........................................................146

Жахина Б.Б. Принципы формирования функциональной грамотности казахского языка.......................................... 151

Идресова У.Х., Садуахасова 3.Ж., Муханова А.Т. Криминалистика......................................................................... 156

Савельева B.B. Исторические и педагогические основы формирования и разработки кредитной технологии

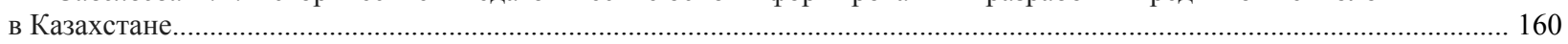

Калиева Т.М., Сембиева Л.М. Национальные ресурсы и богатство нации.................................................. 165

Каримова Р.У., Хаджиева Г.У. К вопросу об этно-политической и социально-экономической трансформации

СУАР в контексте национальной политики КНР

Керимбек Г., Молдашбаева Л., Джрауова Қ., Ажмухамедова А., Мизанова А. Анализ и оценка показателей

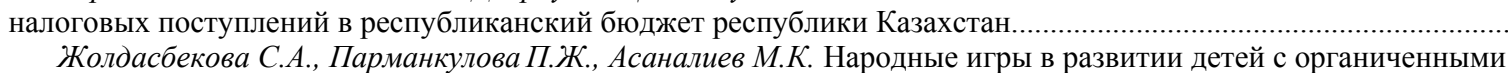

Жолдасбекова С.А., Парманкулова П.Ж., Асаналиев М.К. Народные игры в развитии детей с органиченными

Молдакенова Е.К., Байгабулова К.К., Онаева Б.Т.Пути развития системы регионального аспекта управления

инновационными процессами в АПК.

Муратова Г.К., Шаушенова А.Г., Жумасеитова С.Д., Онгарбаева М.Б. Применение облачных технологий

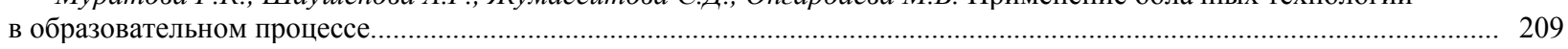

Несипбеков Е.Н., Аппакова Г.Н. Теоретические аспекты формирования инвестиционного портфеля предприятия. 214

Нургабылов М.Н., Барлыков Е.К., Егембердиева С.M. Тенденции управления развитием мясоперерабаты-

вающей отрасли в РК.

Нурымбетов Т.Я., Абишова А.У., Уразбаева Г.Ж., Кыдырова Ж.Ш., Байнеева П.Т., Абишов Н.У. Приоритеты

социальной поддержки населения РК в условиях модернизации................................................................................. 22

Рахимова С. А., Тургумбекова М. М. Программы государственной поддержки мсб в республике Казахстан и меры

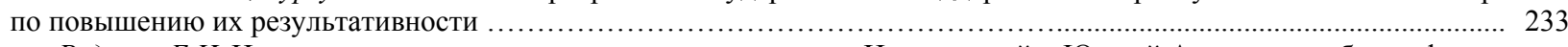

Руденко Е.И. Искаженность восприятия между государствами Центральной и Южной Азии как проблема фактора

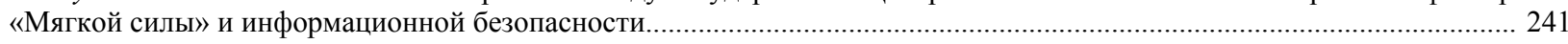

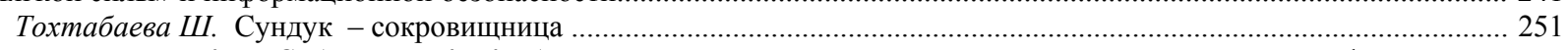

Утепкалиева К.М., Сабирова Р.К., Кенбаева Г.У.Развитие государственно-частного партнерства в нефтегазовой

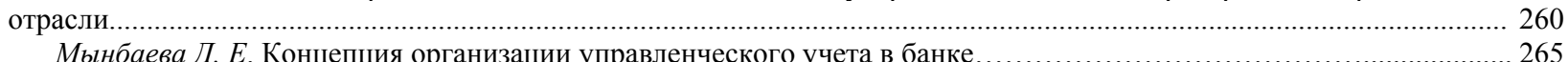

Мынбаева Д. Е. Концепция организации управленческого учета в банке...........................................2.
Султанова Г.С. Педагогические аспекты формирования профессиональных компетенций бакалавра - экономиста

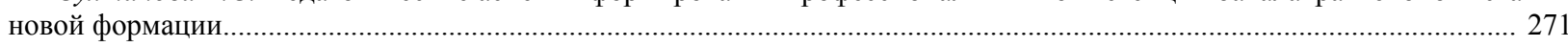

Шаяхметова А.А. О подготовке педагогических кадров к инклюзивному образованию в условиях вуза................ 277 


\section{CONTENTS}

Bespayeva R.S., Bugubayeva R.O., Manuel F. Grela. Formation of the complex strategy for development of the Schuchinsk-

Burabay resort area based on the balanced system of indicators.

Ayupova Z.K., Kussainov D.U., Winston Nagan. Some facets of integration in themodernization ofthe civil process..............13

Kussainova A.A., Kozlowski Waldemar, Gerashchenko I.P. The review of some features of the financial legal mechanism of obligatory social insurance in the republic of Kazakhstan...

Dyussenov B.D. Linguistic features of epigraphic monuments................................................................................ 28

Jumadilova Sh.G., Atabay B.Zh. Dynamics of the population savings in Kazakhstan.......................................................... 33

Karabalina A.A., Alsitova A.B., Kereimaganbetova Zh.N., Abisheva N.M. The values as critical factor of moral education... 42

Kenzhebayeva D.K., Urmurzina B.G., Dashqin Mahammadli. The modern youth values in Kazakhstan............................. 51

Nurmanova A.S., Mederova D.E., Dyussenov B.D. "Bokeykhanov dynasty taldybeyit necropolis" epigraphic monuments

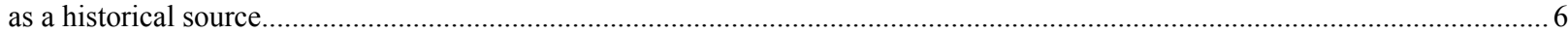

Kydyrova Zh.Sh., Onlasynov E.Z., Abishova A.U., Shadieva A.A.Research of the situation in the market of milk and dairy

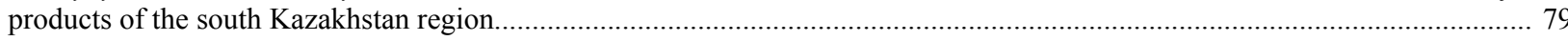

Abishova G.U., Amanzholov R.A., Mynbayeva B.N., Ibragimova D.I. Readiness of students-biologists for the organization

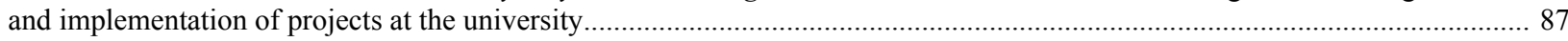

Baltabayeva A.Y., Rizakhojayeva $G$. The phenomenon of the great silk road in the cultural integration process................... 91

Burganova R.I., Abdugalina S.E., Tuyakova A.E. Improving the quality of education through student-centered education... 102

Galiyeva A.Kh., Sadu Zh.N., Kulubekov M.T., Kazbekova L.A. Assessment of the institutional terms of the foreign

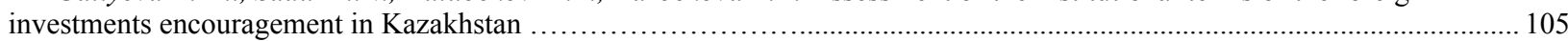

Dzhalilov Z.G. Theoretical discourse on islam and politics in foreign humanism of the second half of 20th century.......... 112

Dzhumabekova A.T., Kanatova A.ZH. Transformation of the transmission mechanism of the national bank of the republic

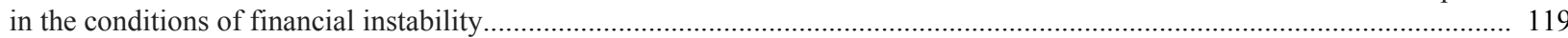

Suleimenov R.B. Problems and features of the development of migration processes in Kazakhstan and Central Asia.......... 124

Yesengulova M.N. Psychological aspects of reintegration and resocialization of "Trouble" adolescents in Kazakhstan....... 134

Zhakisheva K.M., Zhumanova D.T., Mukasheva G.M.The role of monitoring the financial condition of agricultural

enterprises in ensuring sustainable development of the agrarian sector of the economy......................................................... 146

Zhakhina B.B. Principles of functional literacy formation of the kazakh language....................................................... 151

Idresova U.Kh., Saduahasova Z.Zh., Mukhanova A.T. Criminalistics............................................................................. 156

Savelyeva $V . V$. Historicalandpedagogical bases of formation and development of credit technology in Kazakhstan........... 160

Kaliyeva T.M., Sembiyeva L.M. National Resources and national wealth.................................................................. 165

Karimova R., Hajiyeva G. Examining ethno-political and SOCIO-economic transformation of the xinjiang uyghur

autonomous region in the context of the PRC national policies........................................................................................ 176

Kerimbek G., Moldashbayeva L., Jrauova K., Azhmukhamedova A., Misanova A. Analysis and evaluation of reduction

of tax recovery of the republic of kazakhstan on the budget of the republic of Kazakhstan................................................. 185

Zholdasbekova S.A., Parmankulova P.Zh., Assanaliyev M.K. Folk games in the education of children with physical, mental and sensory disturbances..

Moldakenova E.K., Baygabulova K.K., Onaeva B.T. Ways of development of the system of the regional aspect of managing innovative processes in the APC.

Muratova G.K., Shaushenova A.G., Zhumassseitova C.D., Ongarbayeva M.B. Application of cloud technologies in the educational process......

Nurgabylov M.N., Barlikov E.K., Egemberdieva S.M. Trends of management of the development of meat processing industry in RK

Nurymbetov T.Ya., Abishova A.U., Urazbaeva G.Zh., Kydyrova Z.Sh., Baineeva P.T., Abishov N.U. Priorities of social support of the population of republic of Kazakhstan in the conditions of modernization........

Rakhimova S. A., Turgumbekova M. M. Programs of government support for sme in the republic of Kazakhstan and measures to enhance their efficiency.....

Rudenko Ye.I. Misperception between the states of Central and South Asia as a 'Soft power' and information security issue...

Tokhtabayeva Sh. Zh. Treasure-chest.

Utepkalieva K.M., Sabirova R.K., Kenbaeva G.U.Development of public private partnership approach in oil and gas

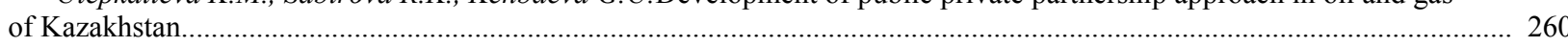

Mynbayeva D.E. Concept of organization of management accounting in bank ........................................................... 265

Sultanova G. S. Pedagogical aspects of formation of professional competence of the bachelor-economist of the new formation

Shayakhmetova A.A. On the training of teaching staff for inclusive education under the conditions of higher education institution. 


\section{PUBLICATION ETHICS AND PUBLICATION MALPRACTICE IN THE JOURNALS OF THE NATIONAL ACADEMY OF SCIENCES OF THE REPUBLIC OF KAZAKHSTAN}

For information on Ethics in publishing and Ethical guidelines for journal publication see http://www.elsevier.com/publishingethics and http://www.elsevier.com/journal-authors/ethics.

Submission of an article to the National Academy of Sciences of the Republic of Kazakhstan implies that the work described has not been published previously (except in the form of an abstract or as part of a published lecture or academic thesis or as an electronic preprint, see $\mathrm{http} / / / \mathrm{www} . e l s e v i e r . c o m / p o s t i n g p o l i c y)$, that it is not under consideration for publication elsewhere, that its publication is approved by all authors and tacitly or explicitly by the responsible authorities where the work was carried out, and that, if accepted, it will not be published elsewhere in the same form, in English or in any other language, including electronically without the written consent of the copyrightholder. In particular, translations into English of papers already published in another language are not accepted.

No other forms of scientific misconduct are allowed, such as plagiarism, falsification, fraudulent data, incorrect interpretation of other works, incorrect citations, etc. The National Academy of Sciences of the Republic of Kazakhstan follows the Code of Conduct of the Committee on Publication Ethics (COPE), and follows the COPE Flowcharts for Resolving Cases of Suspected Misconduct (http://publicationethics.org/files/u2/New_Code.pdf). To verify originality, your article may be checked by the originality detection service Cross Check http://www.elsevier.com/editors/plagdetect.

The authors are obliged to participate in peer review process and be ready to provide corrections, clarifications, retractions and apologies when needed. All authors of a paper should have significantly contributed to the research.

The reviewers should provide objective judgments and should point out relevant published works which are not yet cited. Reviewed articles should be treated confidentially. The reviewers will be chosen in such a way that there is no conflict of interests with respect to the research, the authors and/or the research funders.

The editors have complete responsibility and authority to reject or accept a paper, and they will only accept a paper when reasonably certain. They will preserve anonymity of reviewers and promote publication of corrections, clarifications, retractions and apologies when needed. The acceptance of a paper automatically implies the copyright transfer to the National Academy of sciences of the Republic of Kazakhstan.

The Editorial Board of the National Academy of sciences of the Republic of Kazakhstan will monitor and safeguard publishing ethics. 
Правила оформления статьи для публикации в журнале смотреть на сайте:

\section{www:nauka-nanrk.kz}

\section{social-human.kz}

Редакторы М.С. Ахметова, Т.А. Апендиев, Д.С. Аленов

Верстка на компьютере А.М. Кульгинбаевой

Подписано в печать 08.12.2018

Формат 60x881/8. Бумага офсетная. Печать - ризограф.

17,7 п.л. Тираж 500. Заказ 6.

Национальная академия наук $Р К$

050010, Алматы, ул. Шевченко, 28, т. 272-13-18, 272-13-19 